\title{
Current ecological understanding of fungal-like pathogens of fish: what lies beneath?
}

\section{Rodolphe E. Gozlan ${ }^{1,2 *}$, Wyth L. Marshall ${ }^{3}$, Osu Lilje ${ }^{4}$, Casey N. Jessop ${ }^{4}$, Frank H. Gleason ${ }^{4}$ and Demetra Andreou ${ }^{2}$}

1 Unité Mixte de Recherche Biologie des Organismes et Écosystèmes Aquatiques (IRD 207, CNRS 7208, MNHN, UPMC), Muséum National d'Histoire Naturelle, Paris Cedex, France

${ }^{2}$ Centre for Conservation Ecology and Environmental Sciences, School of Applied Sciences, Bournemouth University, Poole, Dorset, UK

${ }^{3}$ BC Centre for Aquatic Health Sciences, Campbell River, BC, Canada

${ }^{4}$ School of Biological Sciences, University of Sydney, Sydney, NSW, Australia

\section{Edited by:}

Télesphore Sime-Ngando, Centre National de la Recherche, France

\section{Reviewed by:}

Ryan J. Newton, University of

Wisconsin-Milwaukee, USA

Gordon William Beakes, University

of Newcastle, UK

\section{*Correspondence:}

Rodolphe E. Gozlan, Unité Mixte de Recherche Biologie des Organismes et Écosystèmes Aquatiques (IRD 207, CNRS 7208, MNHN, UPMC),

Muséum National d'Histoire Naturelle, 75231 Paris Cedex,

France

e-mail: rudy.gozlan@ird.fr; rgozlan@bournemouth.ac.uk
Despite increasingly sophisticated microbiological techniques, and long after the first discovery of microbes, basic knowledge is still lacking to fully appreciate the ecological importance of microbial parasites in fish. This is likely due to the nature of their habitats as many species of fish suffer from living beneath turbid water away from easy recording. However, fishes represent key ecosystem services for millions of people around the world and the absence of a functional ecological understanding of viruses, prokaryotes, and small eukaryotes in the maintenance of fish populations and of their diversity represents an inherent barrier to aquatic conservation and food security. Among recent emerging infectious diseases responsible for severe population declines in plant and animal taxa, fungal and fungal-like microbes have emerged as significant contributors. Here, we review the current knowledge gaps of fungal and fungal-like parasites and pathogens in fish and put them into an ecological perspective with direct implications for the monitoring of fungal fish pathogens in the wild, their phylogeography as well as their associated ecological impact on fish populations. With increasing fish movement around the world for farming, releases into the wild for sport fishing and human-driven habitat changes, it is expected, along with improved environmental monitoring of fungal and fungal-like infections, that the full extent of the impact of these pathogens on wild fish populations will soon emerge as a major threat to freshwater biodiversity.

Keywords: emerging infectious disease, aquatic, extinction, vertebrate, global, biodiversity, Oomycota, Mesomycetozoea

\section{INTRODUCTION}

Fishes are susceptible to diseases caused by a large number of infectious agents including viruses, bacteria, true fungi, fungallike microrganisms, other protists, and metazoans. This review will briefly discuss true fungal pathogens and then focus on commonly reported zoosporic and amoeboid fungal-like pathogens in the Oomycota and Mesomycetozoea. In general, the number of reported fungal and fungal-like pathogens responsible for diseases in animals is on the increase globally (Fisher et al., 2009; Holdich et al., 2009; Loo, 2009; Frick et al., 2010; Ratnieks and Carreck, 2010; Sarmiento-Ramírez et al., 2010). As such, they are truly emerging diseases with increasing incidence, geographic range, virulence, and some of these fungal and fungal-like pathogens have recently been found in new hosts or are newly discovered (Berger et al., 1998; Brown, 2000; Daszak et al., 2000; Kim and Harvell, 2004; Blehert et al., 2009; Peeler et al., 2010; Cameron et al., 2011). The underpinning drivers of this observed increase remain unclear but these pathogens are known to be opportunistic (Fisher et al., 2012), to have resilient and relatively long-lived environmental stages (Mitchell et al., 2008; Andreou et al., 2009) and may have benefited from recent increase in global trade (Brasier, 2008) and spread of invasive species
(Gozlan et al., 2010). Thus increasingly infectious outbreaks are reported in a broad range of species from coral (Kim and Harvell, 2004) to wheat (Wanyera et al., 2006); notable examples include local extinctions of bats (Frick et al., 2010), bees (Ratnieks and Carreck, 2010), turtles (Sarmiento-Ramírez et al., 2010), amphibians (Fisher et al., 2009) and fish (Gozlan et al., 2005, 2009). In aquatic ecosystems fungi and fungal-like pathogen detection in fish hosts is more complicated due to the lack of direct observation of their hosts contrary to frogs or coral, for example (Gozlan, 2012). This is particularly true in freshwater systems where, despite being responsible for pan-continental population extinctions, some diseases caused by fungal and fungal-like pathogens are chronic with no clear external symptoms (Gozlan et al., 2005; Kocan and Hershberger, 2006; Andreou et al., 2011, 2012). This is very well illustrated, for example, by the rosette agent Sphareothecum destruens, which has been rapidly spreading all over Europe via an invasive healthy fish host carrier (Gozlan et al., 2005; Gozlan, 2012). This fungal-like pathogen is intracellular, causing high mortality (up to 90\%) after about 20-30 days but it can only be confidently detected by PCR analysis (Mendonca and Arkush, 2004). The paradox is that despite huge pan-continental population extinction, it remains difficult to 
characterize the true ecological impact of fungal and fungal-like pathogens on freshwater fish populations.

Despite fisheries representing a key ecosystem service for millions of people around the world, the full appreciation of disease risk associated with fungal pathogen emergence remains limited (Gozlan et al., 2006). Here, we review the current knowledge gaps of fungal microbes in fish, their phylogeography along with the current methods of detection and associated limitations and a global ecological understanding of their impacts on fish host populations. With an increasing volume of fish translocation around the world for farming and sport fishing, the relative absence of fish-infecting fungi outbreaks when compared to other more easily observed taxa exemplifies the current concern of a reporting bias in wild fish populations (Gozlan, 2012).

\section{DIVERSITY AND PHYLOGENY}

In recent years interest in the phylogeny of eukaryotes has been re-evaluated (see Adl et al., 2005). Based on data from sequencing genes, particularly rRNA gene sequences, Baldauf (2003) reassigned eukaryotes into eight different branches or supergroups within the tree of life, namely the opisthokonts, amoebozoa, plants, cercozoa, alveolates, heterokonts, discicristates, and excavates. The true fungi and Mesomycetozoea are placed along with the animals in the Opistokonta. The Mesomycetozoea form a clade, which falls on the animal branch, near the animal fungal divide (Paps et al., 2013). All of the Oomycota are placed into the Heterokont supergroup.

True fungi constitute the most species rich group of organisms on earth with 35 recognized classes and 129 orders (Hibbett et al., 2007). The majority of the fungi causing infection in fish belong to the phylum Ascomycota, with thick-walled non-motile spores (Hibbett et al., 2007). Within the Ascomycota, species from several genera have been reported to be associated with fish infections (Table 1). In addition to the Ascomycota, species belonging to the (earlier diverging) Zygomycota have also been reported to cause disease. The majority of the fungi, which can cause infection in fish are opportunistic and not exclusive parasites of fish. They are most commonly known as plant pathogens (e.g., Penicillium corylophilum and Phoma herbarum), soil fungi (e.g., Paecilomyces lilacinus) and some have even been reported to cause infection in immunosuppressed humans (e.g., Exaphiala xenobiota and Ochroconis humicola).

Branching close to the divergence between fungi and animals there is a relatively recently recognized clade of organisms, the Mesomycetozoea (Mendoza et al., 2002; Ragan et al., 1996), which includes a number of species that are pathogenic to aquatic organisms including fish (Mendoza et al., 2002; Glockling et al., 2013). Within the Mesomycetozoea, species can be divided further into the orders of Dermocystida and Ichthyophonida. The Dermocystida include a number of species that can be pathogenic to fish, the most notable being Sphaerothecum destruens, which can infect a wide range of hosts and has been shown to cause disease and high mortality in cyprinids (Andreou et al., 2011, 2012) and salmonid species (Arkush et al., 1998; Paley et al., 2012). The order also includes numerous Dermocystidium sp., which can infect a variety of fish species (see Table 1). The diversity of the Dermocystidium genus is probably underestimated as a large proportion of recorded cases in the literature only identify the pathogen to genus level. This can be addressed by applying molecular techniques to identify species. Within the Ichthyophonida, Ichthyophonus hoferi is the most common parasite of salt and freshwater fish (Hershberger et al., 2010; Kocan et al., 2010; Gregg et al., 2012; Hamazaki et al., 2013).

The Oomycete parasites of fishes are placed in the Phylum Oomycota and fall into either the saprolegnialean lineage or the peronosporalean lineage. The Oomycetes are water moulds which morphologically resemble fungi, but are taxonomically distinct, encompassing species that are parasitic to a large diversity of host species (Beakes et al., 2012). The majority of the species, which can infect and cause disease in fish belong to the order of Saprolegniales and fall within the genera of Saprolegnia, Aphanomyces and Achlya. A smaller number of species fall within the genus Pythium, a member of the peronsporalean lineage. Twelve species of Saprolegnia and six species each of Aphanomyces and Achlya (Table 1) are more often described in the literature as causing infection in fish; with the most common pathogens of fish being Saprolegnia parasitica and Aphanomyces invadans which have relatively high generalist indices (See Table 1). S. parasitica has been reported to cause disease in 12 fish species whilst $A$. invadans can parasitize 48 fish species.

\section{HOST SPECIFICITY}

A common characteristic of the fish pathogens within Fungi, Mesomycetozoea, and Oomycetes is their generalist nature, with the majority of species infecting and causing disease in fishes across different families (Table 1). All three groups include an equal proportion of species with generalist indices above 3 indicating that they are true generalists (Poulin and Mouillot, 2003). Due to higher reporting and detection of disease in farmed environments, most disease reports are from aquaculture facilities and involve cultured fish species. There is thus a bias in the fish species reported as susceptible to these pathogens and a possible underestimation of their generalist nature (Ramaiah, 2006). A large number of species have a single record of affecting a single fish species in the literature and thus the generalist index cannot be calculated.

The ability of fungal and fungal-like pathogens to infect multiple hosts ("the widest spectrum of host ranges for any group of pathogens" according to Fisher et al., 2012; see Table 1 for fish). often drives high virulence in the most susceptible hosts (Andreou et al., 2012; Huchzermeyer and Van der Waal, 2012). The aspect of generalism in pathogenicity is important due to the fact that generalist pathogens are more likely to emerge through host switching (Woolhouse and Gowtage-Sequeria, 2005), and it is often overlooked (Yamamoto and Kilistoff, 1979; Peeler et al., 2010). However, it is commonly accepted (Ewald, 1994) that in single hosts the optimum level of virulence is determined by the trade-off between virulence and transmissibility (Davies et al., 2001). Thus, the composition of the community and the susceptibility of each host could alter its potential transmissibility and the outcome of infection (Woolhouse et al., 2001). Experimental challenges to fungal and fungal-like pathogens of several fish host species are currently needed. This could involve simple one host one pathogen challenges such as in Andreou et al. (2012) or a 
Table 1 | List of Fungi, Mesomycetozoea and Oomycetes species, which have been recorded as fish parasites in the Web of Knowledge since 1997.

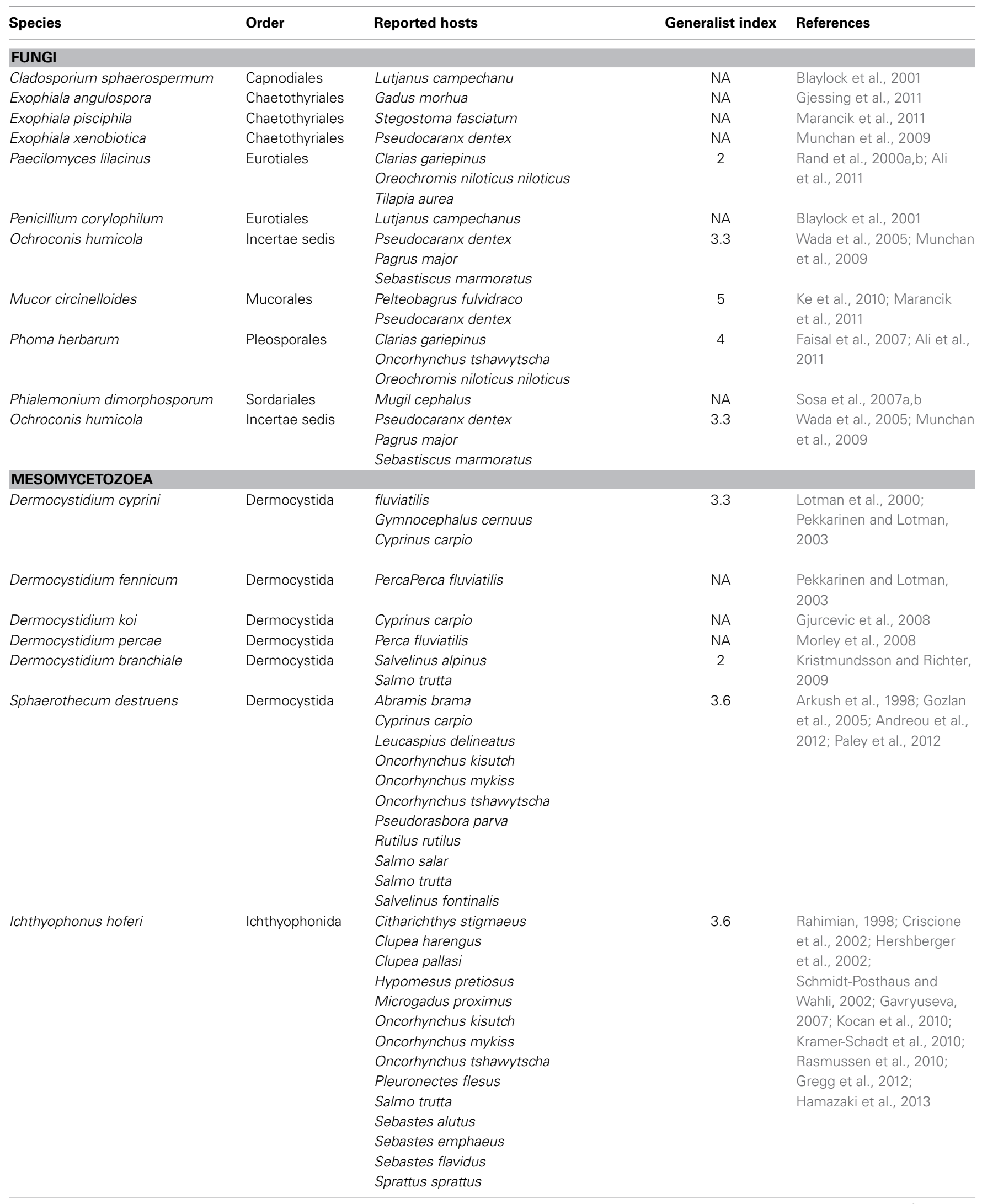


Table 1 | Continued

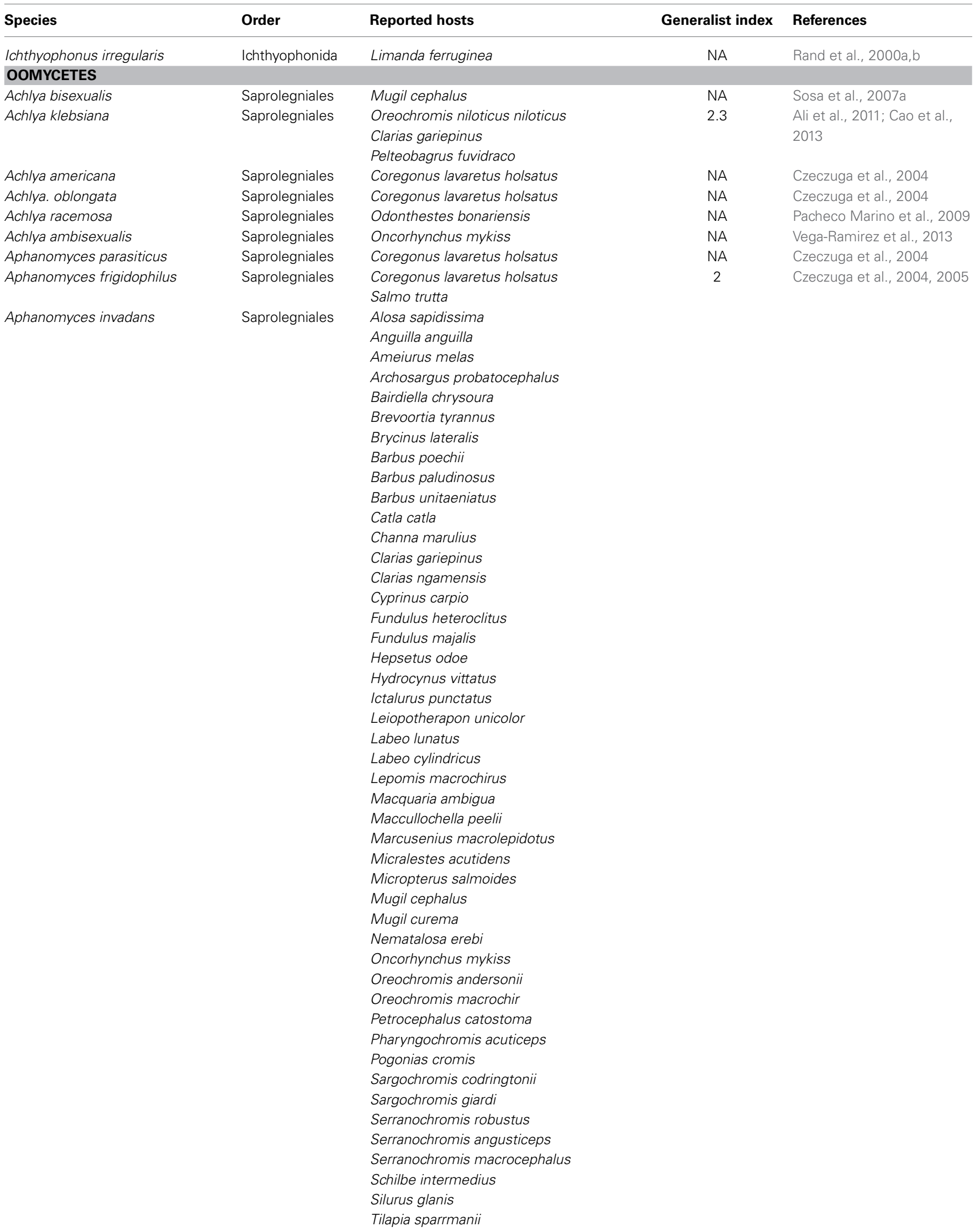


Table 1 | Continued

Species Ord

Tilapia rendalli

Aphanomyces irregularis

Aphanomyces laevis

Aphanomyces salsuginosus

Saprolegnia australis

Saprolegnia brachydanis

Saprolegnia diclina

Saprolegnia furcata

Saprolegnia hypogyana

Saprolegnia parasitica
Order

Reported hosts

Trinectus maculates

Saprolegniales

Saprolegniales

Saprolegniales

Saprolegniales

Saprolegniales

Saprolegniales

Acipencer persicus

Oncorhynchus mykiss Salmo salar eggs

Salmo trutta

Sciaenops ocellatus

Saprolegniales

Carassiuus auratus

Coregonus lavaretus holsatus

Odonthestes bonariensis

Oncorhynchus mykiss eggs

Salmo trutta

Saprolegniales

Salmo trutta

Oncorhynchus mykiss eggs

Salmo trutta

Saprolegniales
Acipencer persicus

Astyanax eigenmanniorum

Astyanax fasciatus

Bidyanus bidyanus

Coregonus lavaretus holsatus

Ictalurus punctatus

Odontesthes bonariensis

Oncorhynchus mykiss

Oncorhynchus masu

eggs Oncorhynchus nerka

Salmo salar eggs Salmo trutta

Salvelinus leucomaenis
Generalist index References

3.7

Thompson et al., 1999;

Hawke et al., 2003;

Harikrishnan et al., 2005;

Kiryu et al., 2005; Webb

et al., 2005; Vandersea

et al., 2006; Sosa et al.,

2007b; Oidtmann et al.,

2008; Saylor et al., 2010;

Boys et al., 2012; Go et al.,

2012; Huchzermeyer and

Van der Waal, 2012; Saikia

and Kamilya, 2012

NA Czeczuga et al., 2004

$4 \quad$ Mondal and De, 2002; Ali

et al., 2011

NA

Takuma et al., 2010

3.3 Hussein et al., 2001; Chang et al., 2002;

Fregeneda-Grandes et al., 2007

NA Ke et al., 2009a,b

3.3 Leano et al., 1999;

Fregeneda-Grandes et al., 2007; Ghiasi et al., 2010;

Shahbazian et al., 2010;

Thoen et al., 2011

3.6 Czeczuga et al., 2004;

Fregeneda-Grandes et al., 2007; Ke et al., 2009a,b; Pacheco Marino et al., 2009; Shahbazian et al., 2010; Cao et al., 2013

NA Fregeneda-Grandes et al., 2007

2 Fregeneda-Grandes et al., 2007; Shahbazian et al., 2010

3.3 Bangyeekhun et al., 2001; Hussein and Hatai, 2002; Czeczuga et al., 2004; Fregeneda-Grandes et al., 2007; Mancini et al., 2008, 2010; Mifsud and Rowland, 2008; Ghiasi et al., 2010; Shahbazian et al., 2010; Thoen et al., 2011 
Table 1 | Continued

\begin{tabular}{|c|c|c|c|c|}
\hline Species & Order & Reported hosts & Generalist index & References \\
\hline Saprolegnia polymorpha & Saprolegniales & Cyprinus carpio & NA & Willoughby, 1998 \\
\hline Saprolegnia salmonis & Saprolegniales & $\begin{array}{l}\text { Coregonus lavaretus holsatus } \\
\text { Oncorhynchus masu } \\
\text { Oncorhynchus mykiss } \\
\text { Oncorhynchus nerka } \\
\text { Plecoglossus altivelis } \\
\text { Salmo trutta } \\
\text { Salvelinus leucomaenis }\end{array}$ & 2.4 & $\begin{array}{l}\text { Hussein et al., 2001; } \\
\text { Chang et al., 2002; } \\
\text { Hussein and Hatai, } 2002 \\
\text { Czeczuga et al., 2004, } \\
2005\end{array}$ \\
\hline Saprolegnia shikotsuensis & Saprolegniales & Coregonus lavaretus holsatus & NA & Czeczuga et al., 2005 \\
\hline Pythium aquatile & Pythiales & Coregonus lavaretus holsatus & NA & Czeczuga et al., 2004 \\
\hline Pythium pulchrum & Pythiales & Coregonus lavaretus holsatus & NA & Czeczuga et al., 2004 \\
\hline Pythium thalassium & Pythiales & Coregonus lavaretus holsatus & NA & Czeczuga et al., 2004 \\
\hline Pythium torulosum & Pythiales & Coregonus lavaretus holsatus & NA & Czeczuga et al., 2004 \\
\hline
\end{tabular}

A generalist index was calculated for each parasite using the method described in Poulin and Mouillot (2003); where species with two or more hosts can have generalist indices ranging from 1 (all host species share the same genus) to 5, using the five taxonomic levels of genus, family, order, class, and phylum. NA stands for non-applicable as the index cannot be calculated when only one host has been reported. The fish taxonomy proposed by Nelson (1994) was used in calculating all generalist indices.

combination of multi-hosts challenges. In addition, experimental data on the free-living elements of these life cycles of pathogens such as the presence of zoospores, would allow the measurement of their production, longevity in the system and their resistance to a range of abiotic factors (e.g., temperature, $\mathrm{PH}$ ). These data are needed to build reliable models to test host susceptibility, understand the controlling factors of infectious phase as well as the recovery phase typical of SIT or SEIR epidemiological models (susceptible-exposed-infectious-recovered).

\section{LIFE CYCLES AND STAGES}

In the assimilative phases of oomycetes and most of the true fungi, colonization of new tissues is accomplished through the growth of hyphae, with the exception of the black yeasts, Exophiala, which may transition between yeast and hyphal forms (dimorphism) (de Hoog et al., 2011). Mesomycetozoeans more often grow as round multinucleate coenocytes. These can be concentrated in visible cysts in the genus Dermocystidium (e.g., Lotman et al., 2000) or disseminated or nodular in S. destruens and Ichthyophonus (Sindermann and Scattergood, 1954; Arkush et al., 1998). Hyphal forms have been described in some Dermocystidium (Dykova and Lom, 1992) and are common in Ichthyophonus (Sindermann and Scattergood, 1954; Rand, 1994; Franco-Sierra and AlvarezPellitero, 1999). Only true fungi, however, have septate hyphae, although some oomycetes have segmented or plugged thalli and thus are also compartmentalized.

All fungal and fungal-like pathogens have prolific asexual reproduction (r-strategy) functioning for dispersal or further dissemination within the host. In the fungi, this is through the production of conidiospores (Ascomycota) or sporangiospores (Zygomycota), and the budding of yeast stages. These spores are not motile and are protected by a chitinous cell wall. The durability and resilience of these spores is an important adaptation for increasing opportunities to encounter new susceptible hosts (Fisher et al., 2012). These spores can survive in a dormant state during conditions unfavorable for growth. Oomycetes produce biflagellated zoospores within sporangia, usually located either at the terminal ends of hyphae. These spores function to disperse the parasite between hosts and typically encyst after a short period of motility. In Saprolegnia species longer lived secondary zoospores emerge from cysts produced by primary zoospores. This pattern of re-emergence called polyplanetism, may be repeated several times (Bruno et al., 2011), and most likely functions to allow several opportunities to contact a new host. Zoospores of many oomycetes are chemotactic, responding to amino acids, carbohydrates and a range of aldehyde attractants (Donaldson and Deacon, 1993). The encysted zoospores of S. parasitica are decorated by long hooked hairs that are thought to aid in attachment to the fish host (Van West, 2006; Walker and Van West, 2007).

Reproduction in the Mesomycetozoea is more varied (Mendoza et al., 2002). S. destruens produce non-motile walled endospores which may either infect other cells within the same host or spread and infect a new host (Arkush et al., 2003). Endospores also produce singly flagellate zoospores upon exposure to fresh water (Arkush et al., 2003) but it is not clear whether these zoospores are infective (Paley et al., 2012). Dermocystidium has similar development with zoospore development within spores, but zoospores are infective (Olson et al., 1991). Released endospores of both Dermocystidium salmonis and $S$. destruens have the capacity to release zoospores for several weeks at $4^{\circ} \mathrm{C}$ (Olson et al., 1991; Andreou et al., 2009). The life cycle of Ichthyophonus is less understood and varies with $\mathrm{pH}$ (Okamoto et al., 1985; Spanggaard et al., 1995; Franco-Sierra and Alvarez-Pellitero, 1999). Single and multinucleate endospores are produced in culture and in vivo (Okamoto et al., 1985; Spanggaard et al., 1995; Franco-Sierra and Alvarez-Pellitero, 1999). Motile zoospores are not produced but amoeboid stages are released under specific $\mathrm{pH}$ optima in culture (e.g., Okamoto et al., 1985). Transmission is also not well understood, except 
that the parasite can be acquired through carnivory (Jones and Dawe, 2002). Kocan et al. (2013) describe small amoeboid stages within the stomach wall of sculpin and trout hosts after feeding of infected tissues and hypothesize that these amoebae represent the infectious stage. The infectious stage of planktivorous fish is still unknown (Gregg et al., 2012) and an alternate host is suspected (Sindermann and Scattergood, 1954).

In parasites of fishes sexual reproduction (s-strategy) has only been described in a few oomycetes. When sexual reproduction occurs, the two dissimilar gametangial structures called the oogonium and the antheridium grow closer together until they fuse, and haploid nuclei from the antheridia fertilize the eggs within the oogonia forming diploid oospores. In free living oomycetes the fertilized zygote, or oospore, is typically resistant and can survive for prolonged periods. Meiosis and recombination occur before germination of the oospore. However, the main oomycete pathogens of live fish (e.g., A. invadans and S. parasitica), do not generally (in case of $A$. invadans never) reproduce sexually and therefore rely entirely on asexual zoosporogenesis (r-strategy). Some egg infecting species do produce oogonia (e.g., S. australis, S. diclina, $S$. ferax) but even in these species oospore germination is rarely if ever observed. It is highly unlikely that oospores serve as effective resistant survival structures for fish parasitic oomycetes. Most true fungal parasites of fish are described as "fungi imperfecti," based on the lack of a described sexual stage.

\section{TROPHIC MODES}

Research on animal parasites has revealed that many of these species are not exclusively saprophytic or parasitic (Gleason et al., 2010; McCreadie et al., 2011). In fact, their precise ecological functions can only be understood with intensive metagenomic investigations, which have rarely been conducted (Jiang et al., 2013). Nonetheless, these microorganisms are frequently characterized as either saprotrophs or biotrophs (Gleason et al., 2010; McCreadie et al., 2011). Saprotrophs usually do not infect live hosts, rather they grow on non-living organic material. In contrast many biotrophs cannot grow outside the host, but some can be grown in culture. Growth of parasites in culture allows research on mechanisms of infection and sequencing genes. Facultative parasites can grow well as either parasites or saprotrophs. Many eukaryotic microorganisms are thought to be parasites primarily because they cannot be grown outside their host, but in fact their trophic relationships remain to be determined. Many Oomycete species are primarily saprotrophs, yet few can become parasites under certain conditions, such as compromised immunity in their hosts. The important point is that they have alternative substrates for growth outside the host, which is an important characteristic of emerging infectious diseases (EID) (Fisher et al., 2012).

\section{PROTEINS AS SUBSTRATES FOR GROWTH}

For a long time proteins have been known to be good substrates for the isolation of Oomycetes into pure culture and for their subsequent growth in liquid media (Sparrow, 1960). For example, casein and keratin can be useful substrates for isolation and growth. Furthermore animal hosts and tissues are known to be protein rich environments. Czeczuga et al. (2002) isolated many species of Oomycetes from specimens of fish muscles placed in freshwater lakes. Some of these specimens came from fish, which were known to be hosts for Oomycetes. Smith et al. (1994) demonstrated proteolytic activity of Saprolegnia diclina, ferax, and parasitica by observing the clearing of casein on solid media. Proteins must be digested extra-cellularly and the amino acids produced must be transported into the cell prior to their catabolism. Jiang et al. (2013) documented the presence of genes for serine, metallo- and cysteine proteases and genes for amino acid transporters in the complete sequence of the genome of $S$. parasitica.

Saprotrophic isolates of Saprolegnia, Achlya, Dictyuchus, Leptolegnia, Aphanomyces, Apodachlya, and Pythium grew rapidly on many but not all amino acids as sole sources of carbon and nitrogen in liquid media (Gleason et al., 1970a,b; Faro, 1971). Alanine, proline, glutamate, aspartate, leucine, lysine, arginine, serine, and phenylalanine were especially good carbon sources, there was very little or no growth on valine, isoleucine, threonine, methionine, and glycine, and there were considerable differences in rates of utilization among the species tested. Saprotrohic and parasitic isolates of Saprolegnia can remove all amino acids from liquid media during growth on mixtures of amino acids (Gleason, 1973; Nolan, 1976). These data indicate that many Oomycetes have the capacity for digestion of proteins and subsequent uptake and catabolism of amino acids. Therefore they commonly grow in protein rich environments. Recently, a few species in the Mesomycetozoea have been grown in culture (Glockling et al., 2013), but nutritional experiments have not been conducted, and little is known about their proteolytic capacities.

\section{CURRENT DETECTION TECHNIQUES}

Lesions formed by parasites were initially characterized from phenotypic, serological and morphological properties of the pathogen. Isolation and culturing of causative organisms from swabbed lesions of infected fish has been an integral part in understanding the taxonomic groupings, etiology of the disease, infectivity, and host-parasite relationships. The process of isolating and identifying pathogens can however be a time consuming process requiring a high level of technical expertise.

Morphological identification of microbial species, which often requires identification of reproductive stages, is difficult to accomplish directly from ulcerated tissue. Direct visualization of pathogens in infected tissues has been made possible with the development of species-specific fluorescent probes. For example, the monoclonal antibody MAb 3gJC9, which is specific for an antigen involved in the pathogenicity of Aphanomyces astaci and $A$. invadans (=piscicida) in infected crayfish and fish respectively, has been used for immunofluorescent identification of these species in infected tissues (Miles et al., 2003). The approach was found to be more sensitive than the conventional staining method, Grocott's methanamine silver stain, in that it enabled the detection of early stages of infection (Grocott, 1955; Miles et al., 2003). Fluorescent hybridization (FISH) probes have also been used to identify specific pathogens in infected tissues in situ. For example, A. invadans was found to be a primary oomycete pathogen in ulcerative mycosis of infected estuarine fish in North Carolina and Florida using a FISH assay (Vandersea et al., 2006; Sosa et al., 2007a,b). Continuing improvements in 
isolation, culturing and in situ approaches is essential for broadening our understanding of disease pathology and etiology and more fundamentally the morphology and physiology of these pathogenic species. In comparison to morphological and physiological classification, the rapid advances in molecular techniques has improved the reliability and accuracy of the tool in distinguishing many taxa, such as the microsporidian taxa (Larsson, 2005). A molecular approach has also led to rapid development of diagnostic tools which involve polymerase chain reaction (PCR), amplification of nucleic acids, restriction enzyme digestion, probe hybridization and nucleotide sequencing. The development of the FISH assay for example was as a result of using a sensitive PCR technique. The use of PCR to detect and identify infections has become commonplace (Tsui et al., 2011). A large number of disease-causing pathogens are often identified to genus level (e.g., Dermocystidium sp.) and not species level. The number of species being identified has been constantly increasing through the use of molecular tools for disease detection and identification. A concerted effort to use the same DNA loci would increase the available genetic information resulting in a better resolution of the phylogenetic relationships within and between these groups. The 18S rRNA gene has been used extensively (for Fungi and Mesomycetozoans); however the Internal Transcribed Sequence 1 (ITS1) has been more extensively used within the Oomycetes. As documented by Diéguez-Uribeondo et al. (2007) for the $S$. diclina-S. parasitica complex, both molecular and morphological and physiological data can help solve phylogenetic relationships. Thus, using ITS rRNA gene, five phylogenetic separate clades were identified for the Saprolegnia complex, with all isolates collected from salmonid lesions falling into a single clade (i.e., clade I). However, within that clade I, parasitic isolates came from a wide range of hosts including, for example, crustaceans, and catfish but also non-pathogenic isolates from soil and water. Molecular analyses have the potential to discriminate at the subspecies or strain level (Phadee et al., 2004). The level of sensitivity of the molecular techniques in the clinical context has however been sporadic (Cunningham, 2002). This is largely due to the relatively low genomic information that is available through public data bases such as Genbank. We propose that all reported cases of disease outbreaks should have both of these regions sequenced and reported within the literature. The use of these loci will allow both detection at species level (18S rRNA) and identification of different strains (using ITS1) within the same species; allowing for a better identification and detection of virulent strains. This collection of information alongside morphological and physiological data will increase the resolution of the phylogenetic information and the sensitivity of molecular identification.

Alternative detection approaches include loop-mediated isothermal amplification (LAMP) and pyrolysis mass spectrometry. LAMP has the potential of increasing sensitivity of pathogen compared to PCR and unlike PCR it is not inactivated by tissue and blood-derived inhibitors or genomic DNA (Savan et al., 2005). It has been used in the detection of trypanosome infection (Savan et al., 2005). Pyrolysis mass spectrometry profile and canonical variate analysis have been used to demonstrate clusters of A. invadans isolates and discriminate them from non-pathogenic Aphanomyces species
(Lilley et al., 2001). The development and refinement of multiple approaches of detection have their place in increasing the knowledge of the pathogen, its distribution, impact and possible management.

\section{IMPORTANCE OF FUNGAL PATHOGENS IN AQUACULTURE}

Fish represent a key ecosystem service for fisheries and aquaculture across the world (Zhao et al., 2014). The annual harvest is about 42 million tonnes (marine and freshwater) and the sector employs 33.1 million people, highlighting the tremendous social cost of fisheries (Gozlan and Britton, 2014). The livelihoods of 60 million people in the developing world are dependent on river fisheries and millions more rely on them for food (Dugan and Allison, 2010). However, disease in aquaculture represents the most significant economic losses and in particular fungal infections, which in terms of economic impact are second only to bacterial diseases (Neish and Hughes, 1980; Noga, 1993; Bruno et al., 2011; Ramaiah, 2006; Van West, 2006; Gonçalves and Gagnon, 2011). For example it has been reported in Japan some annual losses of $50 \%$ in the production of coho salmon Oncorhynchus kisutch and elvers of eel Anguilla Anguilla due to outbreaks of $S$. parasitica (Hatai and Hoshai, 1994; Scarfe, 2003).

In the last decades, the aquaculture sector has seen a change in the fish production with a trend toward intensification with the use of recirculating systems (Larkin and Sylvia, 1999). The underpinning drive was a reduction of environmental footprint, a better control of the rearing environment and increased biosecurity. Nonetheless, this improved control of rearing conditions, has lead the industry to also increase the stocking densities of target fish. Thus, it has resulted in an increase of disease outbreaks, with faster transmission and increased mortalities (Bondad-Reantaso et al., 2005; Whittington and Chong, 2007; Peeler et al., 2010; Gonçalves and Gagnon, 2011).

One of the key risks associated with this new aquaculture environment is the stress caused by intensive production. Some fungal pathogens such as Saproglegnia for example are more prevalent and virulent in host (salmonids in particular) that are raised under stressful conditions (Willoughby and Pickering, 1977; Willoughby, 1978; Jeney and Jeney, 1995). However, other significant pathogen risks in aquaculture arise from the large and frequent movement of young stages due to either a lack of or insufficient national production, or due to fish species for which the life cycle has not yet been mastered at a commercial level, or even contaminated sources of water supplies. Of course this is not specific to fungal or fungal-like pathogens but their generalist and opportunistic nature associated with a wide environmental tolerance are risk factors that may lead to significant loss of production (Harrell et al., 1986; Paley et al., 2012).

In addition, mycoses spread in fishes are often seen as a secondary phenomenon. However, due to their virulence, their current emergence in wild fish populations and also the risk of spill back from aquaculture facilities to the wild, routine pathological examination should include (in addition to bacteriological ones) mycological examination (see Rehulka, 1991 for details). Dominant fungal pathogens reported in aquaculture are oomycetes including the genera Achlya, Aphanomyces and Saprolegnia (Willoughby and Pickering, 1977; Blazer and 
Wolke, 1979; Noga, 1993). A. invadans for example can cause epizootic ulcerative syndrome in over a hundred of mostly freshwater fish (e.g., Vishwanath et al., 1998; Blazer et al., 2013; Nsonga et al., 2013) but also in some brackish fish species (Catap and Munday, 2002; Sosa et al., 2007b). In aquaculture conditions, the most appropriate control is through eradication of the stock, quarantine of new stocks and good husbandry (Scarfe, 2003; Whittington and Chong, 2007) and as such represent a significant cost to the trade (Forneris et al., 2003).

There are no treatments that are specific to fungal and fungallike pathogens but existing ones such as the use of hydrogen peroxide or formalin (Arndt et al., 2001), malachite green (Van West, 2006), sodium chloride (Schreier et al., 1996) and bronopol (Shinn et al., 2012) all present some significant issues related to either human or fish health or to efficacy of the treatments (Carana et al., 2012). Malachite green was banned by the US and EU in early nineties and since then formalin has probably been the most effective control measure but there is a strong possibility that this will soon also be banned from use. Other treatment such as bronopol and other agents are not as effective. Other treatments such as the use of ozone in recirculating systems have to be specifically adapted for fugal pathogens. For example, studies have shown that ozone treatments for Saprolegnia are effective with doze from about 0.01 to $0.2 \mathrm{mg} . \mathrm{L}^{-1}$ (Gonçalves and Gagnon, 2011) but present a cost of through reduction in hatching rates (e.g., 42.6-49.1\%). New treatments based on plant extract have shown some promising paths but further evaluations need to be performed before its use by the industry (Carana et al., 2012).

\section{ECOLOGICAL IMPACT ON WILD POPULATIONS}

The emergence of infectious diseases caused by fungal and fungal-like microbes continues to negatively impact wild fish populations, leading in some cases to local and pan-continental extinctions (Gozlan et al., 2005, 2010; Rowley et al., 2013). Thus, understanding of the true ecological cost of fungal and fungallike microbes is pivotal to improve our conservation practices of fish populations, especially freshwater species, as declines in populations, species distributions and species diversity continue to occur at alarming rates (Myers, 1993; Singh, 2002; Romansic et al., 2009).

Fungal and fungal-like microbes that cause disease emergence in wild fish (Table 2), crayfish, amphibians and other aqutic taxa include Saprolegnia, Batrachochytrium, Ichthyophonous, Aphanomyces, Achyla and Sphaerothecum (Bruno et al., 2011; Swei et al., 2011). Saprolegnia and Sphaerothecum spp. are impacting wild salmon populations around the world (Willoughby et al., 1983; Van West, 2006; Andreou et al., 2009), prevailing in 32\% of adult late-fall-run chinook salmon returning to Battle Creek on the Upper Sacramento River (Arkush et al., 1998). Aphanomyces spp. are also responsible for causing EIDs, for example, Epizootic Ulcerative Syndrome (EUS) commonly known as red spot in over a hundred freshwater and estuarine fish species worldwide (Chinabut et al., 1995; Lilley et al., 1997; Boys et al., 2012). EUS has been recognized in Australia (Huchzermeyer and Van der Waal, 2012) and the Philippines (Callinan et al., 1995) since 1972 and 1995 respectively, however in 2006 this fungal pathogen was sighted in the Zambezi River System (ZRS), Africa, the pathogen had travelled further along the ZRS inhabiting several new ecosystems (Huchzermeyer and Van der Waal, 2012; Nsonga et al., 2013). Additionally, Aphanomcyes spp. low host specificity increases its prevalence among a range of species, increasing disease outbreaks in the ZRS, which is home to approximately eighty species and thus becoming a great concern in disease control (Huchzermeyer and Van der Waal, 2012).

However, compared to farmed fish populations, monitoring EIDs in wild populations can prove difficult as fish are constantly moving long distances beneath turbid waters, which means they can go undetected and underreported distorting our understanding of the effects on these populations (Gozlan, 2012). Globally, EIDs have caused high mortalities in farmed populations (TortoAlalibo et al., 2005; Phillips et al., 2008; Van Den Berg et al., 2013). This is important information for wild populations because there are several instances where transmission of fungal and fungal-like microbes can occur between the two environments. For example, farmed fisheries often drain into rivers (Andreou et al., 2012) allowing the transfer of microbes and other organisms (Krkosek et al., 2005; Hilborn, 2006). Pseudorasbora parva (topmouth gudgeon), widely known by its aquaculture and ornamental fish trade, is a healthy carrier of S. destruens (Gozlan et al., 2005). Originally and unintentionally imported from China, the topmouth gudgeon's propitious nature has allowed it to become a profound invader in wild environments, invading thirty five new countries over the past 40 years, where for example $S$. destruens was identified in river systems of the Netherlands and the UK, posing great threats to native fish populations (Gozlan et al., 2010; Spikmans et al., 2013).

Previous studies have shown that susceptibility of farmed fish to fungal or fungal-like microbes depends on several factors including rapid drops in ambient temperatures (Bly et al., 1993; Lategan et al., 2004), low water levels, failure to remove dead fish or eggs, primary infection by other organisms, (Piper et al., 1982; Plumb, 1984) and pollution (Wu et al., 2010), all of which can reduce ecosystem function (Chapin et al., 2000; Cowx and Gerdeaux, 2004; Peeler et al., 2010) and lead to an increase in EIDs (Woolhouse and Gowtage-Sequeria, 2005). Thus, we could expect that such environmental drivers at play in the wild would potentially have also a direct impact on the emergence of fungal pathogens. In particular, the recent paper by Vörösmarty et al. (2010) shows that $65 \%$ of rivers worldwide regarding thermal and water level disturbances are under moderate-high threat, in particular Asia and North America. However, Vörösmarty et al. (2010) goes on further to highlight the fact that there is a lack of knowledge and investment being directed to biodiversity conservation, with an increase in EIDs, species distinctions, human population, climate change and habitat destruction (Vörösmarty et al., 2010; Huchzermeyer and Van der Waal, 2012; Nsonga et al., 2013). It will be important to monitor these river systems and to reduce these pressures, consequently allowing the populations, species distributions and diversity of fish to remain sustainable for the future.

\section{PERSPECTIVES AND CONCLUSIONS}

Since, the initial discovery of the fungal chytrid pathogen 20 years ago (Berger et al., 1998), several studies have reported its 
Table 2 | Example of fungal infections in wild fish population.

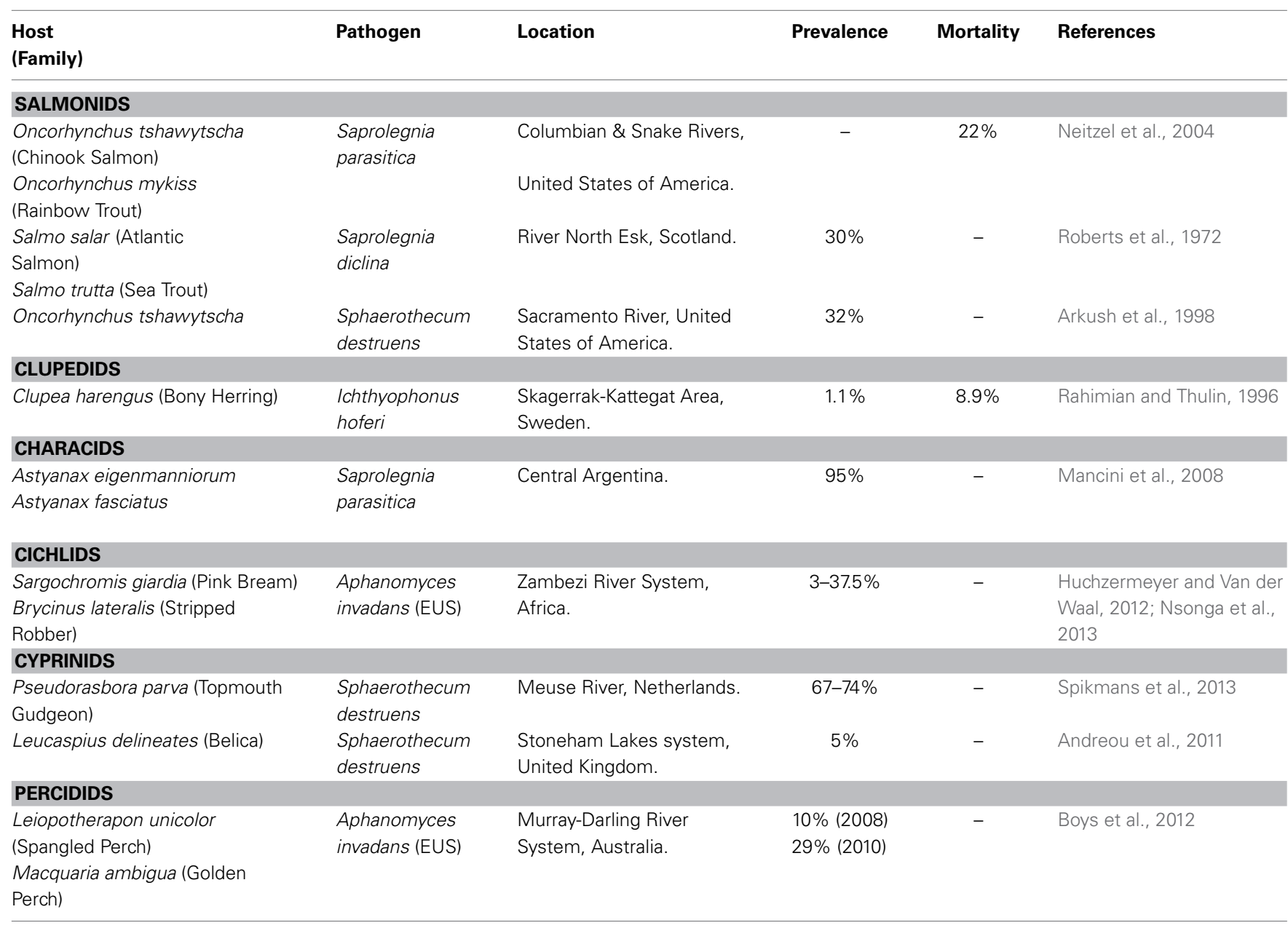

significant impact on amphibians along with major population declines worldwide (Skerratt et al., 2007). What is interesting with this particular pathogen is the relatively good epidemiological data, which have allowed the progression of the disease to be tracked on a global scale and in many wild amphibian populations.

However, there is currently not enough epidemiological data related to fungal pathogens of fish. In light of the recent emergence of $S$. destruens, which poses a threat to European fish diversity (Gozlan et al., 2005; Andreou et al., 2012), it is likely that patterns of ecological impacts similar to those found in chytrid parasites of amphibians, are at play in freshwater fish populations (Gozlan, 2012). For example, as the great majority of S. destruens cases are driven by the invasion of a healthy fish carrier, it is expected, as shown by Spikmans et al. (2013), that additional monitoring of invaded wild fish communities would show the presence of this fungal-like infectious pathogen. In fact, there is not enough fungal pathogen data mostly for fish from wild populations. It is interesting to note that the dominant reporting of fish fungal and fungal-like pathogens has come from the aquaculture sector with very limited reports on fungal emergence in wild fish populations (see Table 2). The key reason is likely to be a combination of a lack of external pathological specificity of infected hosts and the chronic nature of some of the diseases caused by these fungal and fungal-like pathogens, which, in contrast to viral pathogens, spread over longer periods of time.

Research should be modeled after the amphibian chytrid research structure with a lot more systematic tracking of these pathogens. For example, the recent paper by McMahon et al. (2013) clearly indicates that even for the chytrid, which has been well studied in the wild, new potential non-amphibian hosts could contribute further to its dispersal, prevalence and virulence. Similarly, it would thus be pertinent to determine if fungal and fungal-like pathogens of fish that have a high generalist index could include non-fish hosts and thus contribute to a wider dissemination of some fungal related diseases beyond the immediate local fish communities. Additional monitoring of wild fishes is also needed. Identification and surveys of environmental drivers of fungal pathogens would improve understanding of the ecological risks of disease emergence in aquatic communities (Copp et al., 2009, 2010). This should also be the concern of the aquaculture sector, as strong pathways exist between wild and farmed fish with truly biosecure fish farms being the exception. The pan-extinction of sunbleak Leucaspius delineatus populations in Europe in less than 40 years should be a reminder of the risk associated with an un-controlled epizooty of fungal pathogens 
(see Gozlan et al., 2005, 2010). Environmental surveys to identify ecological drivers of fungal pathogens in fishes are also key in characterizing the underpinning drivers of fungal and fungal-like pathogen emergence. For example, fish fungal pathogen emergence such as the EUS in Africa could well be linked to current environmental changes occurring in African rivers (Vörösmarty et al., 2010). Thus, in light of the importance of freshwater fish for millions of people around the world, particularly in developing countries, in addition to biodiversity conservation perspectives, pathologists should make a concerted effort to increase their monitoring of fungal pathogens in wild fish populations. Currently, PCR is the method that should be used for monitoring. Along with an increasing reduction in PCR associated cost, their sensitivity and specificity should facilitate such regular monitoring of the wild fish compartment.

In conclusion, our review of fungal and fungal-like pathogens of fish has highlighted current knowledge gaps that need to be rapidly filled if future epizootics are to be prevented. It has also indicated that epidemiological elements arising from other non-fish specific fungal pathogens could be used to refine our true understanding of current and future ecological impacts of these types of pathogens on global fish diversity. For example, existing experimental data arising from fungal pathogen challenges of fish should be used to develop SEIR models (i.e., susceptible-exposed-infectious-recovered) specific to fungal pathogens and fish hosts. This would allow a simulation of the true extent of the ecological risk and provide elements for a better environmental monitoring and understanding of these types of pathogens.

\section{REFERENCES}

Adl, S. M., Simpson, A. G. B., Farmer, M. A., Andersen, R. A., Anderson, O. R., Barta, J. R., et al. (2005). The new higher level classification of eukaryotes with emphasis on the taxonomy of protists. J. Eukar. Microbiol. 52, 399-451. doi: 10.1111/j.1550-7408.2005.00053.x

Ali, E. H., Hashem, M., and Al-Salahy, M. B. (2011). Pathogenicity and oxidative stress in Nile tilapia caused by Aphanomyces laevis and Phoma herbarum isolated from farmed fish. Dis. Aquat. Organ. 94, 17-28. doi: 10.3354/dao 02290

Andreou, D., Arkush, K. D., Guégan, J.-F., and Gozlan, R. E. (2012). Introduced pathogens and native freshwater biodiversity: a case study of Sphaerothecum destruens. PLoS ONE 7:e36998. doi: 10.1371/journal.pone.0036998

Andreou, D., Feist, S. W., Stone, D., Bateman, K., and Gozlan, R. E. (2011). Sphaerothecum destruens pathology in cyprinids. Dis. Aquat. Organ. 95, 145-151. doi: 10.3354/dao02356

Andreou, D., Gozlan, R. E., and Paley, R. (2009). Temperature influence on production and longevity of Sphaerothecum destruens zoospores. J. Parasitol. 95, 1539-1541. doi: 10.1645/GE-2124.1

Arkush, K. D., Frasca, S., and Hedrick, R. P. (1998). Pathology associated with the Rosette Agent, a systemic protist infecting salmonid fishes. J. Aquat. Anim. Health 10, 1-11. doi: 10.1577/1548-8667(1998)010\%3C0001:PAWTRA\%3E2. $0 . \mathrm{CO} ; 2$

Arkush, K. D., Mendoza, L., Adkison, M. A., and Hedrick, R. P. (2003). Observations on the life stages of Sphaerothecum destruens n.g., n. sp., a Mesomycetozoean fish pathogen formally referred to as the Rosette Agent. J. Eukar. Microb. 50, 430-438. doi: 10.1111/j.1550-7408.2003.tb00269.x

Arndt, R. E., Wagner, E. J., and Routledge, M. E. (2001). Reducing or withholding hydrogen peroxide treatment during a critical stage of rainbow trout development: effects on eyed eggs, hatch, deformities, and fungal control. N. Am. J. Aquacult. 63, 161-166. doi: 10.1577/1548-8454(2001)063\%3C0161: ROWHPT\%3E2.0.CO;2

Baldauf, S. L. (2003). The deep roots of Eukaryotes. Science 300, 1703-1706. doi: $10.1126 /$ science. 1085544
Bangyeekhun, E., Quiniou, S. M. A., Bly, J. E., and Cerenius, L. (2001). Characterisation of Saprolegnia sp isolates from channel catfish. Dis. Aquat. Organ. 45, 53-59. doi: 10.3354/dao045053

Beakes, G. W., Glockling, S. L., and Sekimoto, S. (2012). The evolutionary phylogeny of the oomycete "fungi." Protoplasma 249, 3-19. doi: 10.1007/s00709011-0269-2

Berger, L., Speare, R., Daszak, P., Greene, D., Cunningham, A. A., Goggin, C. L., et al. (1998). Chytridiomycosis causes amphibian mortality associated with population declines in the rain forests of Australia and Central America. Proc. Nat. Acad. Sci. U.S.A. 95, 9031-9036. doi: 10.1073/pnas.95.15.9031

Blaylock, R. B., Overstreet, R. M., and Klich, M. A. (2001). Mycoses in red snapper (Lutjanus campechanus) caused by two deuteromycete fungi (Penicillium corylophilum and Cladosporium sphaerospermum). Hydrobiologia 460, 221-228. doi: 10.1023/A:1013124214166

Blazer, V. S., Volgelbein, W. K., Densmore, C. L., May, E. B., Lilley, J. H., and Zwerner, D. E. (2013). Aphanomyces as a cause of Ulcerative Skin Lesions of Menhaden from Chesapeake Bay tributaries. J. Aquat. Anim. Health. 11, 340-349. doi:10.1577/1548-8667(1999)011<0340:AAACOU>2.0.CO;2

Blazer, V. S., and Wolke, R. E. (1979). An exopholia-like fungus as the cause of a systematic mycosis of marine fish. J. Fish Dis. 2, 145-152. doi: 10.1111/j.13652761.1979.tb00151.x

Blehert, D. S., Hicks, A. C., Behr, M., Meteyer, C. U., Berlowski-Zier, B. M., Buckles, E. L., et al. (2009). Bat white-nose syndrome: an emerging fungal pathogen? Science. 323, 227. doi: 10.1126/science.1163874

Bly, J. E., Lawson, L. A., Szalai, A. J., and Clem, L. W. (1993). Environmentalfactors affecting outbreaks of winter Saprolegniosis in Channel catfish, Ictalurus punctatus (Rafinesque). J. Fish Dis. 16, 541-549. doi: 10.1111/j.13652761.1993.tb00890.x

Bondad-Reantaso, M. G., Subasinghe, R. P., Arthur, J. R., Ogawa, K., Chinabut, S., Adlard, R., et al. (2005). Disease and health management in Asian aquaculture. Vet. Parasitol. 132, 249-272. doi: 10.1016/j.vetpar.2005.07.005

Boys, C. A., Rowland, S. J., Gabor, M., Gabor, L., Marsh, I. B., Hum, S., et al. (2012). Emergence of epizootic ulcerative syndrome in native fish of the murray-darling river system, australia: hosts, distribution and possible vectors. PLOS ONE 7:e35568. doi:10.1371/journal.pone.0035568

Brasier, C. M. (2008). The biosecurity threat to the UK and global environment from international trade in plants. Plant Pathol. 57, 792-808. doi: 10.1111/j.1365-3059.2008.01886.x

Brown, C. (2000). "Emerging diseases of animals-an overview," in Emerging Diseases of Animals, eds C. Brown and C. Bolin (Washington, DC: ASM Press), 1-5.

Bruno, D. W., Van West, P., and Beakes, G. W. (2011). "Saprolegnia and other oomycetes," in Fish Diseases and Disorders. Viral, Bacterial and Fungal Infections, Vol. 3, eds P. T. K. Woo and D. W. Bruno (Wallingford; Oxon: CABI Publishing), 599-659. doi: 10.1079/9781845935542.0669

Callinan, R. B., Paclibare, J. O., Bondad-Reantaso, M. G., Chin, J. C., and Gogolewski, R. P. (1995). Aphanomyces species associated with epizootic ulcerative syndrome (EUS) in the Philippines and red spot disease (RSD) in Australia: preliminary comparative studies. Dis. Aquat. Orgn. 21, 233-238. doi: 10.3354/dao021233

Cameron, S. A., Lozier, J. D., Strange, J. P., Koch, J. B., Cordes, N., Solterd, L. F., et al. (2011). Patterns of widespread decline in North American bumble bees. Proc. Natl. Acad. Sci. U.S.A. 108, 662-667. doi: 10.1073/pnas.1014 743108

Cao, H., Ou, R., He, S., and Yang, X. (2013). Identification of an Achlya klebsiana isolate as the causal agent of Saprolegniosis in eggs of yellow catfish (Pelteobagrus fuvidraco) and control with herbal extracts. Isr. J. Aquacult.-Bamid. Available online at: http://www.siamb.org.il/article-1181-IJA-65-2013-851.aspx

Carana, S., Yoon, G. H., Freeman, M. A., Mackie, J. A., and Shinn, A. P. (2012). The efficacy of selected plant extracts and bioflavonoids in controlling infections of Saprolegnia australis (Saprolegnia; Oomycetes). Aquaculture. 359, 146-154. doi: 10.1016/j.aquaculture.2012.06.035

Catap, E. S., and Munday, B. L. (2002). Development of a method for reproducing epizootic ulcerative syndrome using controlled doses of Aphanomyces invadans in species with different salinity requirements. Aquaculture. 209, 35-47. doi: 10.1016/S0044-8486(01)00805-5

Chang, P. H., Wu, T. P., Chung, H. Y., and Chien, C. Y. (2002). Aeromonas hydrophila and Saprolegnia australis isolated from Ayu, Plecoglossus altivelis with ulcerative skin disease in Taiwan. Bull. Eur. Assoc. Fish Patho. 22, 
393-399. Available online at: http://eafp.squarespace.com/bulletin-archive/ 2002-volume-22/issue-6/

Chapin, F. S., Zavaleta, E. S., Eviner, V. T., Naylor, R. L., Vitousek, P. M., Reynolds, H. L., et al. (2000). Consequences of changing biodiversity. Nature. 405, 234-242. doi: 10.1038/35012241

Chinabut, S., Roberts, R. J., Willoughby, L. G., and Pearson, M. D. (1995). Histopathology of snakehead, Channa striatus (Bloch), experimentally infected with the specific Aphanomyces fungus associated with epizootic ulcerative syndrome (EUS) at different temperatures. J. Fish Dis. 18, 41-47. doi: 10.1111/j. 1365-2761.1995.tb01264.x

Copp, G. H., Vilizzi, L., Mumford, J., Godard, M. J., Fenwick, G., and Gozlan, R. E. (2009). Calibration of FISK, an invasiveness screening tool for nonnative freshwater fishes. Risk Anal. 29, 457-467. doi: 10.1111/j.1539-6924.2008. 01159.x

Copp, G. H., Villizi, L., and Gozlan, R. E. (2010). Fish movements: the introduction pathway for topmouth gudgeon Pseudorasbora parva and other non-native fishes in the UK. Aquat. Conserv. 20, 269-273. doi: 10.1002/ aqc. 1092

Cowx, I. G., and Gerdeaux, D. (2004). The effects of fisheries management practises on freshwater ecosystems. Fish. Manag. Ecol. 11, 145-151. doi: 10.1111/j.13652400.2004.00411.x

Criscione, C. D., Watral, V., Whipps, C. M., Blouin, M. S., Jones, S. R. M., and Kent, M. L. (2002). Ribosomal DNA sequences indicate isolated populations of Ichthyophonus hoferi in geographic sympatry in the north-eastern Pacific Ocean. J. Fish Dis. 25, 575-582. doi: 10.1046/j.1365-2761.2002.00404.x

Cunningham, C. (2002). Molecular diagnosis of fish and shellfish diseases: present status and potential use in disease control. Aquaculture 206, 19-55. doi: 10.1007/ s12161-010-9132-x

Czeczuga, B., Bartel, R., Kiziewicz, B., Godlewska, A., and Muszynska, E. (2005). Zoosporic fungi growing on the eggs of sea trout (Salmo trutta m. trutta L.) in river water of varied trophicity. Pol. J. Environ. Stud. 14, 295-303. Available online at: http://www.pjoes.com/abstracts/2005/Vol14/No03/list.html

Czeczuga, B., Kiziewicz, B., and Danilkiewicz, Z. (2002). Zoosporic fungi growth on the specifmens of certain fish species recently introduced tp Polish waters. Acta Ichthyo. Piscat. 32, 117-126. Available online at: http://www.aiep.pl/volumes/2000/2_2/volume.php

Czeczuga, B., Kiziewicz, B., and Godlewska, A. (2004). Zoosporic fungi growing on eggs of Coregonus lavaretus holsatus Thienemann, 1916 from Lake Wdzydze in Kaszuby. Pol. J. Environ. Stud. 13, 355-359.

Daszak, P., Cunningham, A. A., and Hyatt, A. D. (2000). Emerging infectious diseases of wildlife-threats to biodiversity and human health. Science 287, 443-449. doi: 10.1126/science.287.5452.443

Davies, C. M., Webster, J. P., and Woolhouse, M. E. J. (2001). Tradeoffs in the evolution of virulence in an indirectly transmitted macroparasite. Proc. R. Soc. B Biol. Sci. 268, 251-257. doi: 10.1098/rspb.2000.1367

de Hoog, G. S., Vicente, V. A., Najafzadeh, M. J., Harrak, M. J., Badali, H., and Seyedmousavi, S. (2011). Waterborne Exophiala species causing disease in coldblooded animals. Persoonia 27, 46-72. doi: 10.3767/003158511X614258

Diéguez-Uribeondo, J., Fregeneda-Grandes, J. M., Cerenius, L., Pérez-Iniesta, E., Aller-Gancedo, J. M., Tellería, M. T., et al. (2007). Re-evaluation of the enigmatic species complex Saprolegnia diclina-Saprolegnia parasitica based on morphological, physiological and molecular data. Fung. Genet. Biol. 44, 585-601. doi: 10.1016/j.fgb.2007.02.010

Donaldson, S. P., and Deacon, J. W. (1993). Differential encystment of zoospores of Pythium species by saccharides in relation to establishment on roots. Physiol. Mol. Plant Pathol. 42, 177-184. doi: 10.1006/pmpp.1993.1016

Dugan, P., and Allison, E. H. (2010). Water: act now to restore river health. Nature 468, 173. doi: $10.1038 / 468173 b$

Dykova, I., and Lom, J. (1992). New evidence of fungal nature of Dermocystidium koi Hoshina and Sahara, 1950. J. Appl. Ichth. 8, 180-185. doi: 10.1111/j.14390426.1992.tb00681.x

Ewald, P. W. (1994). Evolution of Infectious Disease. Oxford: Oxford University Press.

Faisal, M., Elsayed, E., Fitzgerald, S. D., Silva, V., and Mendoza, L. (2007). Outbreaks of phaeohyphomycosis in the chinook salmon (Oncorhynchus tshawytscha) caused by Phoma herbarum. Mycopathologia 163, 41-48. doi: 10.1007/s11046-006-0084-z

Faro, S. (1971). Utilization of certain amino acids and carbohydrates as carbon sources by Achlya hetroseualis. Mycologia 63, 1234-1237. doi: 10.2307/3757998
Fisher, M. C., Garner, T. W. J., and Walker, S. F. (2009). Global emergence of Batrachochytrium dendrobatidis andamphibian chytridiomycosis in space, time, and host. Annu. Rev. Microbiol. 63, 291-310. doi: 10.1146/annurev.micro.091208.073435

Fisher, M. C., Henk, D. A., Briggs, C. J., Brownstein, J. S., Madoff, L. C., McCraw, S. L., et al. (2012). Emerging fungal threats to animal, plant and ecosystem health. Nature 484, 186-194. doi: 10.1038/nature10947

Forneris, G., Bellardi, S., Palmegiano, G. B., Saroglia, M., Sicuro, B., Gasco, L., et al. (2003). The use of ozone in trout hatchery to reduce saprolegniasis incidence. Aquaculture 221, 157-166. doi: 10.1016/S0044-8486(02)00518-5

Franco-Sierra, A., and Alvarez-Pellitero, P. (1999). The morphology of Ichthyophonus sp. In their mugilid hosts (Pisces: Teleostei) and following cultivation in vitro. A light and electron microscopy study. Parasitol. Res. 85, 562-575. doi: 10.1007/s004360050596

Fregeneda-Grandes, J. M., Rodriguez-Cadenas, F., and Aller-Gancedo, J. M. (2007). Fungi isolated from cultured eggs, alevins and broodfish of brown trout in a hatchery affected by saprolegniosis. J. Fish Biol. 71, 510-518. doi: 10.1111/j.1095-8649.2007.01510.x

Frick, W. F., Pollock, J. F., Hicks, A. C., Langwig, K. E., Reynolds, D. S., Turner, G. G., et al. (2010). An emerging disease causes regional population collapse of a common North American bat species. Science 329, 679-682. doi: $10.1126 /$ science. 1188594

Gavryuseva, T. V. (2007). First report of Ichthyophonus hoferi infection in young coho salmon Oncorhynchus kisutch (Walbaum) at a fish hatchery in Kamchatka. Russ. J. Marine Biol. 33, 43-48. doi: 10.1134/S106307400701004X

Ghiasi, M., Khosravi, A. R., Soltani, M., Binaii, M., Shokri, H., Tootian, Z., et al. (2010). Characterization of Saprolegnia isolates from Persian sturgeon (Acipencer persicus) eggs based on physiological and molecular data. J. Mycol. Med. 20, 1-7. doi: 10.1016/j.mycmed.2009.11.005

Gjessing, M. C., Davey, M., Kvellestad, A., and Vralstad, T. (2011). Exophiala angulospora causes systemic inflammation in Atlantic cod Gadus morhua. Dis. Aquat. Organ. 96, 209-219. doi: 10.3354/dao02381

Gjurcevic, E., Bambir, S., Kozaric, Z., Kuzir, S., Gavrilovic, A., and Pasalic, I. (2008). Dermocystidium infection in common carp broodstock (Cyprinus carpio L.) from Croatia. Bull. Eur. Assoc. Fish Pathol. 28, 222-229. Available online at: http://eafp.squarespace.com/bulletin-archive/2008-volume-28/issue-6/

Gleason, F. H. (1973). Uptake of Amino Acids by Saprolegnia. Mycologia. 65, 465-468. doi: 10.2307/3758117

Gleason, F. H., Agostina, V., Marano, P. J., and Martin, W. W. (2010). Blastocladian parasites of invertebrates. Fung. Biol. Rev. 24, 56-67 doi: 10.1016/j.fbr.2010.03.004

Gleason, F. H., Rudolph, C. R., and Price, J. S. (1970a). Growth of certain aquatic Oomycetes on amino acids I. Saprolegnia, Achlya, Leptolegnia and Dictyuchus. Physiol. Plant. 23, 513-516. doi: 10.1111/j.1399-3054.1970.tb06442.x

Gleason, F. H., Stuart, T. D., Price, J. S., and Nelbach, W. T. (1970b). Growth of certain aquatic Oomycetes on amino acids II. Apodachlya, Aphanomyces and Pythium. Physiol. Plant. 23, 769-774. doi: 10.1111/j.1399-3054.1970.tb06472.x

Glockling, S. L., Marshall, W. L., and Gleason, F. H. (2013). Phylogenetic interpretations and ecological potentials of the Mesomycetozoea (Ichthyosporea). Fung. Ecol. 6, 237-247. doi: 10.1016/j.funeco.2013.03.005

Go, J., Marsh, I., Gabor, M., Saunders, V., Reece, R. L., Frances, J., et al. (2012). Detection of Aphanomyces invadans and epizootic ulcerative syndrome in the Murray-Darling drainage. Aust. Vet. J. 90, 513-514. doi: 10.1111/j.17510813.2012.01012.x

Gonçalves, A. A., and Gagnon, G. A. (2011). Ozone application in recirculating aquaculture system: an overview, ozone: science \& engineering. J. Int. Ozone Assoc. 33, 345-367. doi: 10.1080/01919512.2011.604595

Gozlan, R. E. (2012). Monitoring fungal infections in fish. Nature 285, 446-447. doi: $10.1038 / 485446 \mathrm{~d}$

Gozlan, R. E., Andreou, D., Asaeda, T., Beyer, K., Bouhadad, R., Burnard, D., et al. (2010). Pan-continental invasion of Pseudorasbora parva: towards a better understanding of freshwater fish invasions. Fish Fisheries 11, 315-340. doi: 10.1111/j.1467-2979.2010.00361.x

Gozlan, R. E., and Britton, J. R. (2014). "Sustainable freshwater fisheries: the search for workable solutions," in Freshwater Fisheries, ed J. Craig (London: Wiley-Blackwell), (in press).

Gozlan, R. E., St-Hilaire, S., Feist, S. W., Longshaw, M., and Peeler, E. J. (2006). The effect of microbial pathogens on the diversity of aquatic populations, notably in Europe. Microb. Infect. 8, 1358-1364. doi: 10.1016/j.micinf.2005.12.010 
Gozlan, R. E., St-Hilaire, S., Feist, S. W., Martin, P., and Kent, M. L. (2005). Disease threats on European fish. Nature 435, 1045-1046. doi: 10.1038/4351046a

Gozlan, R. E., Whipps, C., Andreou, D., and Arkush, K. (2009). Characterisation and geographical isolation of Sphaerothecum destruens in Europe. Int. J. Parasitol. 39, 1055-1058. doi: 10.1016/j.ijpara.2009.04.012

Gregg, J. L., Grady, C. A., Friedman, C. S., and Hershberger, P. K. (2012). Inability to demonstrate fish-to-fish transmission of Ichthyophonus from laboratory infected Pacific herring Clupea pallasii to naïve conspecifics. Dis. Aquat. Organ. 99, 139-144. doi: 10.3354/dao02458

Grocott, R. G. (1955). A stain for fungi in tissue sections and smears using gomoris methenamine-silver nitrate technique. Am. J. Clin. Pathol. 25, 975-979.

Hamazaki, T., Kahler, E., Borba, B. M., and Burton, T. (2013). PCR testing can be as accurate as culture for diagnosis of Ichthyophonus hoferi in Yukon River Chinook salmon Oncorhynchus tshawytscha. Dis. Aquat. Organ. 105, 21-25. doi: 10.3354/dao02606

Harikrishnan, R., Balasundaram, C., and Bhuvaneswari, R. (2005). Restorative effect of Azadirachta indicab aqueous leaf extract dip treatment on haematological parameter changes in Cyprinus carpio (L.) experimentally infected with Aphanomyces invadans fungus. J. Appl. Ichthyol. 21, 410-413. doi: 10.1111/j.1439-0426.2005.00614.x

Harrell, L. W., Elston, R. A., Scott, T. M., and Wilkinson, M. T. (1986). A significant new systemic disease of net-pen reared Chinook salmon (Oncorhynchus tshawytscha) brood stock. Aquaculture 55, 249-262. doi: 10.1016/00448486(86)90167-5

Hatai, K., and Hoshai, G. I. (1994). "Pathogenecity of saprolegnia parasitica coker," in Salmon Saproleniasis, ed G. J. Mueller (Portland, OR: U. S. Department of Energy), 87-98.

Hawke, J. P., Grooters, A. M., and Camus, A. C. (2003). Ulcerative mycosis caused by Aphanomyces invadans in channel catfish, black bullhead, and bluegill from southeastern Louisiana. J. Aquat. Anim. Health 15, 120-127. doi: 10.1577/ H02-039

Hershberger, P. K., Stick, K., Bui, B., Carroll, C., Fall, B., Mork, C., et al. (2002). Incidence of Icthyophonus hoferi in Puget Sound fishes and its increase with age of Pacific Herring. J. Aquat. Anim. Health 14, 50-56. doi: 10.1577/15488667(2002)014<0050:IOIHIP>2.0.CO;2

Hershberger, P. K., van der Leeuw, B. K., Gregg, J. L., Grady, C. A., Lujan, K. M., Gutenberger, S. K., et al. (2010). Amplification and transport of an endemic fish disease by an introduced species. Biol. Invas. 12, 3665-3675. doi: 10.1007/s10530-010-9760-5

Hibbett, D. S., Binder, M., Bischoff, J. F., Blackwell, M., Cannon, P. F., Eriksson, O. E., et al. (2007). A higher-level phylogenetic classification of the Fungi. Mycol. Res. 111, 509-547. doi: 10.1016/j.mycres.2007.03.004

Hilborn, R. (2006). Salmon-farming impacts on wild salmon. Proc. Nat. Acad. Sci. U.S.A. 103, 15277-15277. doi: 10.1073/pnas.0607419103

Holdich, D. M., Reynolds, J. D., Souty-Grosset, C., and Sibley, P. J. (2009). A review of the ever increasing threat to European crayfish from nonindigenous crayfish species. Knowl. Managt. Aquat. Ecosyst. 11, 394-395. doi: $10.1051 / \mathrm{kmae} / 2009025$

Huchzermeyer, K. D. A., and Van der Waal, B. C. W. (2012). Epizootic ulcerative syndrome: exotic fish disease threatens Africa's aquatic ecosystems. J. S. Afr. Vet. Assoc. 83, 1-6. doi: 10.4102/jsava.v83i1.204

Hussein, M. M. A., and Hatai, K. (2002). Pathogenicity of Saprolegnia species associated with outbreaks of salmonid saprolegniosis in Japan. Fish. Sci. 68, 1067-1072. doi: 10.1046/j.1444-2906.2002.00533.x

Hussein, M. M. A., Hatai, K., and Nomura, T. (2001). Saprolegniosis in salmonids and their eggs in Japan. J. Wildl. Dis. 37, 204-207. doi: 10.7589/0090-355837.1.204

Jeney, Z., and Jeney, G. (1995). Recent achievements in studies on diseases of common carp (Cyprinus carpio L.). Aquaculture 129, 397-420. doi: 10.1016/00448486(94)00283-T

Jiang, R. H. Y., de Bruijn, I., Haas, B. J., Belmonte, R., Lõbach, L., Christie, J., et al. (2013). Distinctive expansion of potential virulence genes in the genome of the oomycete fish pathogen Saprolegnia parasitica. PLoS Genet. 9:e1003272. doi: 10.1371/journal.pgen.1003272

Jones, S. R. M., and Dawe, S. C. (2002). Ichthyophonus hoferi Plehn \& Mulsow in British Columbia stocks of Pacific herring, Clupea pallasi Valenciennes, and its infectivity to Chinook salmon, Oncorhynchus tshawytscha (Walbaum). J. Fish Dis. 25, 415-421. doi: 10.1046/j.1365-2761.2002.00390.x
Ke, X., Wang, J., Gu, Z., Li, M., and Gong, X. (2009a). Saprolegnia brachydanis, a new oomycete isolated from zebra fish. Mycopathologia 167, 107-113. doi: 10.1007/s11046-008-9150-Z

Ke, X. L., Wang, J. G., Gu, Z. M., Li, M., and Gong, X. N. (2009b). Morphological and molecular phylogenetic analysis of two Saprolegnia sp (Oomycetes) isolated from silver crucian carp and zebra fish. Mycol. Res. 113, 637-644. doi: 10.1016/j.mycres.2009.01.008

Ke, X., Wang, J., Li, M., Gu, Z., and Gong, X. (2010). First report of Mucor circinelloides occurring on yellow catfish (Pelteobagrus fulvidraco) from China. FEMS Microbiol. Lett. 302, 144-150. doi: 10.1111/j.1574-6968.2009. 01841.x

Kim, K., and Harvell, C. D. (2004). The rise and fall of a six-year coral-fungal epizootic. Am. Nat. 164, S52-S63. doi: 10.1086/424609

Kiryu, Y., Blazer, V. S., Vogelbein, W. K., Kator, H., and Shields, J. D. (2005). Factors influencing the sporulation and cyst formation of Aphanomyces invadans, etiological agent of ulcerative mycosis in Atlantic menhaden, Brevoortia tyrannus. Mycologia 97, 569-575. doi: 10.3852/mycologia.97.3.569

Kocan, R. M., Gregg, J. L., and Hershberger, P. K. (2010). Release of infectious cells from epidermal ulcers in ichthyophonus sp.-infected pacific herring (clupea pallasii): evidence for multiple mechanisms of transmission. J. Parasitol. 96, 348-352. doi: 10.1645/GE-2292.1

Kocan, R., and Hershberger, P. (2006). Differences in Ichthyophonus prevalence and infection severity between upper Yukon River and Tanana River chinook salmon, Oncorhynchus tshawytscha (Walbaum) stocks. J. Fish Dis. 29, 497-503. doi: 10.1111/j.1365-2761.2006.00743.x

Kocan, R., LaPatra, S., and Hershberger, P. (2013). Evidence for an amoeba-like infectious stage of Ichthyophonus sp. and description of a circulating blood stage: a probable mechanism for dispersal within the fish host. J. Parasitol. 99, 235-240. doi: 10.1645/GE-3255.1

Kramer-Schadt, S., Holst, J. C., and Skagen, D. (2010). Analysis of variables associated with the Ichthyophonus hoferi epizootics in Norwegian spring spawning herring, 1992-2008. Can. J. Fish. Aquat. Sci. 67, 1862-1873. doi: 10.1139/ F10-102

Kristmundsson, A., and Richter, S. H. (2009). Parasites of resident arctic charr, Salvelinus alpinus, and brown trout, Salmo trutta, in two lakes in Iceland. Icel. Agri. Sci. 22, 5-18. Available online at: http://www.ias.is/landbunadur/ wgsamvef.nsf/key2/gthor7xwkkc.html

Krkosek, M., Lewis, M. A., and Volpe, J. P. (2005). Transmission dynamics of parasitic sea lice from farm to wild salmon. Proc. R. Soc. B Biol. Sci. 272, 689-696. doi: $10.1098 /$ rspb.2004.3027

Larkin, S. L., and Sylvia, G. (1999). Intrinsic fish characteristics and intraseason production efficiency: a management-level bioeconomic analysis of a commercial fishery. Am. J. Agric. Ecol. 81, 29-43. doi: 10.2307/1244448

Larsson, J. I. R. (2005). Molecular versus morphological approach to microsporidian classification. Folia Parasitol. 52, 143-144. doi: 10.14411/fp.2005.018

Lategan, M. J., Torpy, F. R., and Gibson, L. F. (2004). Biocontrol of saprolegniosis in silver perch Bidyanus bidyanus (Mitchell) by Aeromonas media strain A199. Aquaculture 235, 77-88. doi: 10.1016/j.aquaculture.2003.09.014

Leano, E. M., Vrijmoed, L. L. P., and Jones, E. B. G. (1999). Saprolegnia diclina isolated from pond cultured red drum (Sciaenops ocellatus) in Hong Kong. Mycol. Res. 103, 701-706. doi: 10.1017/S0953756298007643

Lilley, J. H., Beakes, G. W., and Hetherington, C. S. (2001). Characterization of Aphanomyces invadans isolates using pyrolysis mass spectrometry (PyMS). Mycoses. 44, 383-389. doi: 10.1046/j.1439-0507.2001.00668.x

Lilley, J. H., Hart, D., Richards, R. H., Roberts, R. J., Cerenius, L., and Soderhall, K. (1997). Pan-Asian spread of single fungal clone results in large-scale fish kills. Vet. Rec. 140, 653-654. doi: 10.1136/vr.140.25.653

Loo, J. A. (2009). Ecological impacts of non-indigenous invasive fungi as forest pathogens. Biol. Inv. 11, 81-96. doi: 10.1007/s10530-008-9321-3

Lotman, K., Pekkarinen, M., and Kasesalu, J. (2000). Morphological observations on the life cycle of Dermocystidium cyprini Cervinka and Lom, 1974, parasitic in carps (Cyprinus carpio). Acta Prootozool. 39, 125-134.

Mancini, M., Rodriguez, C., Barberis, C., Astoreca, A., and Brol, G. (2010). Saprolegniasis in wild silverside Odontesthes bonariensis (pisces: athernopsidae) of Argentina. Rev. Brasil. Med. Vet. 32, 46-50.

Mancini, M., Rodriguez, C., Bonansea, M., Astoreca, A., Bagnis, G., da Rocha Rosa, C. A., et al. (2008). Saprolegniasis in wild populations of astyanax eigenmanniorum and a. fasciatus (pisces, characidae) from Argentina. Rev. Brasil. Med. Vet. 30, $115-122$. 
Marancik, D. P., Berliner, A. L., Cavin, J. M., Clauss, T. M., Dove, A. D. M., Sutton, D. A., et al. (2011). Disseminated fungal infection in two species of captive sharks. J. Zoo and Wild. Med. 42, 686-693. doi: 10.1638/2010-0175.1

McCreadie, J. W., Adler, P. H., and Beard, C. E. (2011). Ecology of symbiotes of larval black flies (Diptera: Simuliidae): distribution, diversity, and scale. Env. Entomol. 40, 289-302. doi: 10.1603/EN10258

McMahon, T. A., Brannelly, L. A., Chatfield, M. W. H., Johnson, P. T. J., Joseph, M. B., McKenzie, V. J., et al. (2013). Chytrid fungus Batrachochytrium dendrobatidis has non-amphibian hosts and releases chemicals that cause pathology in the absence of infection. Proc. Nat. Acad. Sci. USA. 110, 210-215. doi: 10.1073/pnas. 1200592110

Mendonca, H. L., and Arkush, K. D. (2004). Development of PCR-based methods for detection of Sphaerothecum destruens in fish tissues. Dis. Aqua. Org. 61, 187-197. doi: 10.3354/dao061187

Mendoza, L., Taylor, J. W., and Ajello, L. (2002). The class Mesomycetozoea: A group of microorganisms at the animal-fungal boundary. Ann. Rev. Microbiol. 56, 315-344. doi: 10.1146/annurev.micro.56.012302.160950

Mifsud, C., and Rowland, S. J. (2008). Use of salt to control ichthyophthiriosis and prevent saprolegniosis in silver perch, Bidyanus bidyanus. Aquat. Res. 39, 1175-1180. doi: 10.1111/j.1365-2109.2008.01981.x

Miles, D. J. C., Thompson, K. D., Lilley, J. H., and Adams, A. (2003). Immunofluorescence of the epizootic ulcerative syndrome pathogen, Aphanomyces invadans, using a monoclonal antibody. Dis. Aquat. Organ. 55, 77-84. doi: 10.3354/dao055077

Mitchell, K. M., Churcher, T. S., Garner, T. W. G., and Fisher, M. C. (2008). Persistence of the emerging pathogen Batrachochytrium dendrobatidis outside the amphibian host greatly increases the probability of host extinction. Proc. Royal Soc. B Biol. Sci. 275, 329-334. doi: 10.1098/rspb.2007.1356

Mondal, S. K., and De, A. B. (2002). A fatal oomycotic disease of the fresh water fish Aplocheilus panchax in India caused by Aphanomyces laevis. Mycopathologia 154, 21-24. doi: 10.1023/A:1015252717966

Morley, N. J., Campbell, C., and Lewis, J. W. (2008). The occurrence and distribution of Dermocystidium percae (Mesomycetozoea) in perch (Perca fluviatilis) in the lower Thames Valley, UK. J. Appl. Ichthyol. 24, 629-631. doi: 10.1111/j.14390426.2008.01109.x

Munchan, C., Kurata, O., Wada, S., Hatai, K., Sano, A., Kamei, K., et al. (2009). Exophiala xenobiotica infection in cultured striped jack, Pseudocaranx dentex (Bloch \& Schneider), in Japan. J. Fish Dis. 32, 893-900. doi: 10.1111/j.13652761.2009.01068.x

Myers, N. (1993). Biodiversity and the precautionary principle. AMBIO 22, 74-79.

Neitzel, D. A., Elston, R. A., and Abernethy, C. S. (2004). Prevention of Pre-Spawning Mortality: Cause of Salmon Headburns and Cranial Lesions. Portland, OR: U.S. Army Corps of Engineers. 53. doi: 10.2172/15020751

Neish, G. A. and Hughes, G. C. (1980). Disease of Fishes, Book 6, Fungal Disease of Fishes. Neptune, NJ: T.F.H. Publications. 159.

Nelson, J. S. (1994). Fishes of the World. 3rd Edn. New York, NY: John Wiley \& Sons, Inc.

Noga, E. J. (1993). "Fungal diseases of marine and estuarine fishes," in Pathology of Marine and Estuarine Organisms, eds J. A. Couch and J. W. Fournie (Boca Raton, FL: CRC Press), 85-110.

Nolan, R. A. (1976). Physiological studies on an Isolate of Saprolegnia ferax from the larval gut of the blackfly Simulium vittatum. Mycologia 68, 523-540. doi: $10.2307 / 3758976$

Nsonga, A., Mfitilodze, W., Samui, K. L., and Sikawa, D. (2013). Epidemiology of epizootic ulcerative syndrome in Zambesi River system. A case study for Zambia. Hum. Vet. Med. 5, 1-8. Available online at: http://www.hvm.bioflux. com.ro/home/volume-5-1-2013/

Oidtmann, B., Steinbauer, P., Geiger, S., and Hoffmann, R. W. (2008). Experimental infection and detection of Aphanomyces invadans in European catfish, rainbow trout and European eel. Dis. Aquat. Organ. 82, 195-207. doi: 10.3354/ dao01973

Okamoto, N., Nakase, K., Suzuki, H., Nakai, Y., Fujii, K., and Sano, T. (1985). Life history and morphology of Ichthyophonus hoferi in vitro. Fish Pathol. 20, 273-285. doi: 10.3147/jsfp.20.273

Olson, R. E., Dungan, C. F., and Holt, R. A. (1991). Water-borne transmission of Dermocystidium salmonis in the laboratory. Dis. Aquat. Organ. 12, 41-48. doi: 10.3354/dao012041

Pacheco Marino, S. G., Steciow, M. M., and Barbeito, C. (2009). First report of Saprolegniosis on eggs and a juvenile of "Argentinian silverside" (Odonthestes bonariensis). Bull. Eur. Assoc. Fish Pathol. 29, 10-15. Available online at: http:// eafp.squarespace.com/bulletin-archive/2009-volume-29/issue-1/

Paley, R. K., Andreou, D., Bateman, K. S., and Feist, S. W. (2012). Isolation and culture of Sphaerothecum destruens from Sunbleak (Leucaspius delineatus) in the UK and pathogenicity experiments in Atlantic salmon (Salmo salar). Parasitology 139, 904-914. doi: 10.1017/S0031182012000030

Paps, J., Medina-Chacon, L. A., Marshall, W. L., Suga, H., and Ruiz-Trillo, I. (2013). Molecular phylogeny of Unikonts: new insights into the position Apusozoa and the internal relationships of opisthokonts. Protist 164, 2-12. doi: 10.1016/j.protis.2012.09.002

Peeler, E. J., Oidtmann, B. C., Midtlyng, P. J., Miossec, L., and Gozlan, R. E. (2010). Non-native aquatic animals introductions have driven disease emergence in Europe. Biol. Invas. 13, 1291-1303. doi: 10.1007/s10530-010-9890-9

Pekkarinen, M., and Lotman, K. (2003). Occurrence and life cycles of Dermocystidium species (Mesomycetozoa) in the perch (Perca fluviatilis) and ruff (Gymnocephalus cernuus) (Pisces: Perciformes) in Finland and Estonia. J. Nat. Hist. 37, 1155-1172. doi: 10.1080/00222930110120999

Phadee, P., Kurata, O., Hatai, K., Hirono, I., and Aoki, T. (2004). Detection and identification of fish-pathogenic Aphanomyces piscicida using polymerase chain reaction (PCR) with species-specific primers. J. Aquat. Anim. Health 16, 220-230. doi: 10.1577/H03-047.1

Phillips, A. J., Anderson, V. L., Robertson, E. J., Secombes, C. J., and Van West, P. (2008). New insights into animal pathogenic oomycetes. Trends Microbiol. 16, 13-19. doi: 10.1016/j.tim.2007. 10.013

Piper, R. G., McElwain, I. B., Ormer, L. E., McCraren, J. P., Fowler, L. G., and Leonad, J. R. (1982). Fish Hatchery Management. Washinton, DC: Department of the Interior US Fish and Wildlife Service. 503.

Plumb, J. A. (1984). Relationship of water quality and infectious disease in cultured channel catfish. Symp. Biol. Hungar. 23, 189-198.

Poulin, R., and Mouillot, D. (2003). Parasite specialization from a phylogenetic perspective: a new index of host specificity. Parasitology 126, 473-480. doi: $10.1017 /$ S0031182003002993

Ragan, M. A., Goggin, C. L., Cawthorn, R. J., Cerenius, L., Jamieson, A. V. C. Plourde, S. M., et al. (1996). A novel clade of protistan parasites near the animal-fungal divergence. Proc. Natl. Acad. Sci. U.S.A. 93, 11907-11912. doi: 10.1073/pnas.93.21.11907

Rahimian, H. (1998). Pathology and morphology of Ichthyophonus hoferi in naturally infected fishes off the Swedish west coast. Dis. Aquat. Organ. 34, 109-123. doi: 10.3354/dao034109

Rahimian, H., and Thulin, J. (1996). Epizootiology of Ichthyophonus hoferi in herring populations off the Swedish west coast. Dis. Aquat.Organ. 27, 187-195. doi: $10.3354 /$ dao027187

Ramaiah, N. (2006). A review on fungal diseases of algae, marine fishes, shrimps and corals. Ind. J. Mar. Sci. 35, 380-387. Available online at http://www.niscair.res.in/sciencecommunication/researchjournals/rejour/ijms/ ijms2k6/ijms_dec06.asp

Rand, T. G. (1994). An unusuaul form of Ichthyophonus hoferi (Ichthyophonales: Ichthyophonaceae) from yellowtail flounder Limanda ferruginea from the Nova Scotia shelf. Dis. Aquat. Organ. 18, 21-28. doi: 10.3354/dao018021

Rand, T. G., Bunkley-Williams, L., and Williams, E. H. (2000a). A hyphomycete fungus, Paecilomyces lilacinus, associated with wasting disease in two species of Tilapia from Puerto Rico. J. Aquat. Anim. Health 12, 149-156. doi: 10.1577/1548-8667(200006)012<0149:AHFPLA>2.0.CO;2

Rand, T. G., White, K., Cannone, J. J., Gutell, R. R., Murphy, C. A., and Ragan, M. A. (2000b). Ichthyophonus irregularis sp nov from the yellowtail flounder Limanda ferruginea from the Nova Scotia shelf. Dis. Aquat. Organ. 41, 31-36. doi: 10.3354/dao041031

Rasmussen, C., Purcell, M. K., Gregg, J. L., LaPatra, S. E., Winton, J. R., and Hershberger, P. K. (2010). Sequence analysis of the internal transcribed spacer (ITS) region reveals a novel clade of Ichthyophonus sp from rainbow trout. Dis. Aqua. Org. 89, 179-183. doi: 10.3354/dao02184

Ratnieks, F. L. W., and Carreck, N. L. (2010). Clarity on honey bee collapse? Science 327, 152-153. doi: 10.1126/science. 1185563

Rehulka, J. (1991). "Prevention and therapy of fish diseases: fungal diseases," in Diagnostics, prevention and therapy of fish diseases and intoxications, eds J. Tesarèik and Z. Svobodová (Rome: FAO), 270-307.

Roberts, R. J., Shearer, W. M., and Munro, A. L. S. (1972). Studies on ulcerative dermal necrosis of salmonids; IV: Failure to detect epithelial antibodies in 
sera from diseased fish. J. Fish Biol. 4, 21-25. doi: 10.1111/j.1095-8649.1972.tb 05648.x

Rowley, J. J. L., Gleason, F. H., Andreou, D., Marshall, W. L., Lilje, O., and Gozlan, R. E. (2013). Impacts of mesomycetozoean parasites on amphibian and freshwater fish populations. Fung. Ecol. 27, 100-111. doi: 10.1016/j.fbr.2013.09.002

Romansic, J. M., Diez, K. A., Higashi, E. M., Johnson, J. E., and Blaustein, A. R. (2009). Effects of the pathogenic water mold Saprolegnia ferax on survival of amphibian larvae. Dis. Aquat. Organ. 83, 187-193. doi: 10.3354/dao02007

Saikia, D., and Kamilya, D. (2012). Immune responses and protection in catla (Catla catla) vaccinated against epizootic ulcerative syndrome. Fish Shell. Immunol. 32, 353-359. doi: 10.1016/j.fsi.2011.11.030

Sarmiento-Ramírez, J. M., Abella, E., Martín, M. P., Tellería, M. T., López-Jurado, L. F., Marco, A., et al. (2010). Fusarium solani is responsible for mass mortalities in nests of loggerhead sea turtle, Caretta caretta, in Boavista, Cape Verde. FEMS Microbiol. Lett. 312, 192-200. doi: 10.1111/j.1574-6968.2010. 02116.x

Savan, R., Kono, T., Itami, T., and Sakai, M. (2005). Loop-mediated isothermal amplification: an emerging technology for detection of fish and shellfish pathogens. J. Fish Dis. 28, 573-581. doi: 10.1111/j.1365-2761.2005. 00670.x

Saylor, R. K., Miller, D. L., Vandersea, M. W., Bevelhimer, M. S., Schofield, P. J., and Bennett, W. A. (2010). Epizootic ulcerative syndrome caused by Aphanomyces invadans in captive bullseye snakehead Channa marulius collected from south Florida, USA. Dis. Aquat. Organ. 88, 169-175. doi: 10.3354/dao02158

Scarfe, A. D. (2003). "State, regional, national, and international aquatic animal health policies: focus for future aquaculture biosecurity," in Biosecurity in Aquaculture Production Systems: Exclusion of Pathogens and Other Undesirables, eds C. S. Lee and P. J. O'Bryen (Baton Rouge, LA: The World Aquaculture Society), 233-262.

Schmidt-Posthaus, H., and Wahli, T. (2002). First report of Ichthyophonus hoferi infection in wild brown trout (Salmo trutta) in Switzerland. Bull. Eur. Assoc. Fish Pathol. 22, 225-228.

Schreier, T. M., Rach, J. J., and Howe, G. E. (1996). Efficacy of formalin, hydrogen peroxide, and sodium chloride on fungal-infected rainbow trout eggs. Aquaculture 140, 323-331. doi: 10.1016/0044-8486(95)01182-X

Shahbazian, N., Mousavi, E. H. A., Soltani, M., Khosravi, A. R., Mirzargar, S., and Sharifpour, I. (2010). Fungal contamination in rainbow trout eggs in Kermanshah province propagations with emphasis on Saprolegniaceae. Iran. J. Fish. Sci. 9, 151-160.

Shinn, A. P., Picon-Camacho, S. M., Bron, J. E., Conway, D., Ha Yoon, G., Ci Guo, F., et al. (2012). The anti-protozoal activity of bronopol on the key life-stages of Ichthyophthirius multifiliis Fouquet, 1876 (Ciliophora). Vet. Parasitol. 186 229-236. doi: 10.1016/j.vetpar.2011.11.025

Sindermann, C. J., and Scattergood, L. W. (1954). Diseases of fishes of the western North Atlantic. II. Ichthyosporidium disease of the sea herring (Clupea harengus). Res. Bull. Sea Shore Fish. 19, 1-40.

Singh, J. S. (2002). The biodiversity crisis: a multifaceted review. Curr. Sci. 82, 638-647.

Skerratt, L. F., Berger, L., Speare, R., Cashins, S., McDonald, K. R., Phillott, A. D. et al. (2007). Spread of chytridiomycosis has caused the rapid global decline and extinction of frogs. EcoHealth 4, 125-134. doi: 10.1007/s10393-007-0093-5

Smith, S. N., Chohan, R., Howitt, S. G., and Armstrong, R. A. (1994). Proteolytic activity amongst selected Saprolegnia species. Mycol. Res. 98, 389-395. doi: 10.1016/S0953-7562(09)81194-5

Sosa, E. R., Landsberg, J. H., Kiryu, Y., Stephenson, C. M., Cody, T. T., Dukeman, A. K., et al. (2007a). Pathogenicity studies with the fungi Aphanomyces invadans, Achlya bisexualis, and Phialemonium dimorphosporum: Induction of skin ulcers in striped mullet. J. Aquat. Anim. Health 19, 41-48. doi: 10.1577/ H06-013.1

Sosa, E. R., Landsberg, J. H., Stephenson, C. M., Forstchen, A. B., Vandersea, M. W., and Litaker, R. W. (2007b). Aphanomyces invadans and ulcerative mycosis in estuarine and freshwater fish in Florida. J. Aquat. Anim. Health 19, 14-26. doi: 10.1577/H06-012.1

Spanggaard, B., Huss, H. H., and Bresciani, J. (1995). Morphoogy of Ichthyophonus hoferi assessed by light and scanning electron microscopy. J. Fish Dis. 18, 567-577. doi: 10.1111/j.1365-2761.1995.tb00361.x

Sparrow, F. K. (1960). Aquatic Phycomycetes, 2nd Edn. Michigan, IN: The University of Michigan Press.
Spikmans, F., van Tongeren, T., van Alen, T. A., van der Velde, G., and den Camp, H. J. O. (2013). High prevalence of the parasite Sphaerothecum destruens in the invasive topmouth gudgeon Pseudorasbora parva in the Netherlands, a potential threat to native freshwater fish. Aquat. Invasions 8, 355-360. doi: 10.3391/ai.2013.8.3.12

Swei, A., Rowley, J. J. L., Rodder, D., Diesmos, M. L. L., Diesmos, A. C., Briggs, C. J., et al. (2011). Is chytridiomycosis an emerging infectious disease in Asia? PLoS ONE 6:e23179. doi: 10.1371/journal.pone.0023179

Takuma, D., Sano, A., Wada, S., Kurata, O., and Hatai, K. (2010). A new species, Aphanomyces salsuginosus sp nov., isolated from ice fish Salangichthys microdon. Mycoscience 51, 432-442. doi: 10.1007/S10267-010-0058-3

Thoen, E., Evensen, O., and Skaar, I. (2011). Pathogenicity of Saprolegnia spp. to Atlantic salmon, Salmo salar L., eggs. J. Fish Dis. 34, 601-608. doi: 10.1111/j.1365-2761.2011.01273.x

Thompson, K. D., Lilley, J. H., Chen, S. C., Adams, A., and Richards, R. H. (1999). The immune response of rainbow trout (Oncorhynchus mykiss) against Aphanomyces invadans. Fish Shell. Immunol. 9, 195-210. doi: 10.1006/fsim. 1998.0198

Torto-Alalibo, T., Tian, M., Gajendran, K., Waugh, M. E., van West, P., and Kamoun, S. (2005). Expressed sequence tags from the oomycete fish pathogen Saprolegnia parasitica reveal putative virulence factors. BMC Microbiology 5:46 doi: 10.1186/1471-2180-5-46

Tsui, C. K. M., Woodhall, J., Chen, W., Lévesque, C. A., Lau, A., Schoen, C. D., et al. (2011). Molecular techniques for pathogen identification and fungus detection in the environment. IMA Fungus 2, 177-189. doi: 10.5598/imafungus.2011.02.02.09

Van Den Berg, A. H., Mclaggan, D., Dieguez-Uribeondo, J., and Van West, P. (2013). The impact of the water moulds Saprolegnia diclina and Saprolegnia parasitica on natural ecosystems and the aquaculture industry. Fungal Biol. Rev. 27, 33-42. doi: 10.1016/j.fbr.2013.05.001

Vandersea, M. W., Litaker, R. W., Yonnish, B., Sosa, E., Landsberg, J. H. Pullinger, C., et al. (2006). Molecular assays for detecting Aphanomyces invadans in ulcerative mycotic fish lesions. Appl. Env. Microb. 72, 1551-1557. doi: 10.1128/AEM.72.2.1551-1557.2006

Van West, P. (2006). Saprolegnia parasitica, an oomycete pathogen with a fishy appetite: new challenges for an old problem. Mycologist 20, 99-104. doi: 10.1016/j.mycol.2006.06.004

Vega-Ramirez, M. T., Moreno-Lafont, M. C., Valenzuela, R., Cervantes-Olivares, R., Miguel Aller-Gancedo, J., Fregeneda-Grandes, J. M., et al. (2013). New records of Saprolegniaceae isolated from rainbow trout, from their eggs, and water in a fish farm from the State of Mexico. Rev. Mex. De Biod. 84, 637-649. doi: $10.7550 / \mathrm{rmb} .28627$

Vishwanath, T. S., Mohan, C. V., and Shankar, K. M. (1998). Epizooic Ulcerative Syndrome (EUS), associated with a fungal pathogen, in Indian fishes: histopathology - "a cause for invasiveness." Aquaculture 165, 1-9. doi: 10.1016/S0044-8486(98)00227-0

Vörösmarty, C. J., McIntyre, P. B., Gessner, M. O., Dudgeon, D., Prusevich, A., Green, P., et al. (2010). Global threats to human water security and river biodiversity. Nature 467, 555-561. doi: 10.1038/nature09440

Wada, S., Hanjavanit, C., Kurata, O., and Hatai, K. (2005). Ochroconis humicola infection in red sea bream Pagrus major and marbled rockfish Sebastiscus marmoratus cultured in Japan. Fish. Sci. 71, 682-684. doi: 10.1111/j.14442906.2005.01016.x

Walker, C. A., and Van West, P. (2007). Zoospore development in the oomycetes. Fungal. Biol. Rev. 21, 10-18. doi: 10.1016/j.fbr.2007.02.001

Wanyera, R., Kinyua, M. G., Jin, Y., and Singh, R. P. (2006). The spread of stem rust caused by Puccinia graminis $\mathrm{f}$. sp. tritici, with virulence on $\mathrm{Sr} 31$ in wheat in Eastern Africa. Plant Dis. 90, 113-113. doi: 10.1094/PD-90-0113A

Webb, S. R., Garman, G. C., McIninch, S. P., Nerad, T. A., Peglar, M. T., Gillevet, P. M. et al. (2005). Etiology of ulcerative lesions of Atlantic menhaden (Brevoortia tyrannus) from James River, Virginia. Parasitol. Res. 97, 358-366. doi: 10.1007/s00436-005-1437-0

Whittington, R. J., and Chong, R. (2007). Global trade in ornamental fish from Australian perspective: The case for revised import risk analysis and management strategies. Prev. Vet. Med. 81, 92-116. doi: 10.1016/j.prevetmed.2007.04.007

Willoughby, L. G. (1978). Saprolegnias of salmonid fish in Windermere: a critical analysis. J. Fish. Dis. 1, 51-67. doi: 10.1111/j.1365-2761.1978.tb00005.x 
Willoughby, L. G. (1998). Saprolegnia polymorpha sp. nov., a fungal parasite on Koi carp, in the UK. Nova Hedwigia 66, 507-511.

Willoughby, L. G., and Pickering, A. D. (1977). Viable Saprolegniaceae spores on the epidermis of the salmonid fish Salmo trutta and Salvelinus alpinus. Trans. Br. Mycol. Soc. 68, 91-95. doi: 10.1016/S0007-1536(77)80157-5

Willoughby, L. G., Pickering, A. D., and Johnson, H. G. (1983). Polycell-gel assay of water for spores of Saprolegniaceae (fungi), especially those of the Saprolegnia pathogen of fish. Hydrobiologia 114, 237-248. doi: 10.1007/ BF00031875

Woolhouse, M. E. J., and Gowtage-Sequeria, S. (2005). Host range and emerging and reemerging pathogens. Emerg. Infect. Dis. 11, 1842-1847. doi: 10.3201/eid1112.050997

Woolhouse, M. E. J., Taylor, L. H., and Haydon, D. T. (2001). Population biology of multihost pathogens. Science 292, 1109-1112. doi: 10.1126/science.1059026

Wu, W. L., Wang, J. L., Liu, L. C., Jiang, J., Chen, Y., Hu, T., et al. (2010). Identification and characterization of microbial agents in a bloom of floating microorganisms in the Hailang River, China in 2006. Chin. J. Ocean. Limnol. 28, 836-841. doi: 10.1007/s00343-010-9060-z

Yamamoto, T., and Kilistoff, J. (1979). Infectious pancreatic necrosis virus: quantification of carriers in lake populations during a 6-year period. J. Fish Res. Board Can. 36, 562-567. doi: 10.1139/f79-080
Zhao, Y., Gozlan, R. E., and Zhang, C. (2014). "Current state of freshwater fisheries in China," in Freshwater Fisheries, ed J. Craig (London: Wiley-Blackwell), (in press).

Conflict of Interest Statement: The authors declare that the research was conducted in the absence of any commercial or financial relationships that could be construed as a potential conflict of interest.

Received: 03 October 2013; accepted: 30 January 2014; published online: 19 February 2014.

Citation: Gozlan RE, Marshall WL, Lilje O, Jessop CN, Gleason FH and Andreou $D$ (2014) Current ecological understanding of fungal-like pathogens of fish: what lies beneath? Front. Microbiol. 5:62. doi: 10.3389/fmicb.2014.00062

This article was submitted to Aquatic Microbiology, a section of the journal Frontiers in Microbiology.

Copyright (๑ 2014 Gozlan, Marshall, Lilje, Jessop, Gleason and Andreou. This is an open-access article distributed under the terms of the Creative Commons Attribution License (CC BY). The use, distribution or reproduction in other forums is permitted, provided the original author(s) or licensor are credited and that the original publication in this journal is cited, in accordance with accepted academic practice. No use, distribution or reproduction is permitted which does not comply with these terms. 